\title{
Message Received? The Role of Emotion, Race, and Politics in Social Movement Perceptions and Support
}

\author{
Lauren Valentino, Duke University \\ D. Adam Nicholson, Indiana University
}

\section{Acknowledgements:}

The authors wish to thank Stephen Benard; Long Doan, Fabio Rojas; Lynn Smith Lovin; Dawn

Robinson; Stephen Vaisey; Joan Valentino; the Duke University Culture and Cognition Workshop; the Indiana University Politics, Economy, and Culture Workshop; and the Center for Research on Race and Ethnicity in Society (CRRES) at Indiana University.

\section{Keywords:}

social movements, race and ethnicity, culture and cognition, politics, emotions

\section{Corresponding author:}

D. Adam Nicholson

Department of Sociology Department of Sociology

744 Ballantine Hall

1020 E. Kirkwood Ave.

Bloomington, IN 47405-7103

Email: nicholda@indiana.edu 


\begin{abstract}
Scholars have long studied how social movements frame and deliver their messages, yet much less is known about how these "signals" are received by the public. In this study, we ask whether and how social movement members' characteristics interact with a bystander's to influence whether they support a particular protest movement. In addition, we examine how perceived likelihood of violence mediates these outcomes. We test five competing models based on previous theories of emotion, race, and political views in social movement support. To adjudicate between these frameworks, we conduct an experiment using a $2 \times 2$ factorial design in which participants read a news story about a protest accompanied by an image of a neutral/angry, white/Black protestor, measuring three types of social movement support. Results provide support for the politicized race model: a Black protestor is more motivating for liberals' social movement support, while a white protestor is more motivating for conservatives. Both liberals and conservatives are more likely to associate the protest with violence after seeing a Black protestor compared to a white one. Racialized perceptions of violence explain part of conservatives' hesitancy to support the movement when seeing a Black protestor and inhibits part of the otherwise-positive effect of seeing a Black protestor for liberals.
\end{abstract}

\title{
BACKGROUND
}

Social movements are important engines of social change. One key way social movements effect this change is by shifting or amplifying public opinion (Amenta et al. 2010; Agnone 2007; Giugni 1998; Burstein 1985). Elected politicians in representative democracies are sensitive to public opinion (Soroka and Wlezien 2010), and successful social movement organizations leverage this interest to meet their goals (Fassiotto and Soule 2017; Wouters and Walgrave 2017). 
Given the important intermediary role of public opinion in the way social movements engender concrete change, much social movement research has focused on the strategies social movement organizations undertake to convince bystanders that the movement is legitimate and its cause worth supporting. This line of work is the focus of the highly generative research program that examines collective action frames - a research program which has highlighted the discursive and strategic techniques social movements use to convince others that the issue they have identified is indeed problematic, that the solution they are offering is indeed viable, and that supporting the movement will indeed help to bring about the solution to the problem (see Benford and Snow 2000 for a review).

While we now know much about the "signal" side of the process - that is, how social movement actors engage in this framing work -, researchers are just beginning to turn their analytic focus to the "receiver" side of the process - that is, how the public understands and interprets these various signals. Studies of how social movements influence policymakers find that factors like the clarity of a social movement's message, perceived unity among a movement's members, and the size of protest events are important in shaping whether and how political decision-makers take resultant action (Fassiotto and Soule 2017; Wouters and Walgrave 2017). Moving beyond policymakers to the general public, Andrews, Beyerlein, and Farnum (2016) find that a person's exposure to nearby protest events and the politics of the community in which they are embedded shaped individuals' views on the Civil Rights movement.

As mobilization research begins to examine the way a movement's "signals" are received, two key theoretical insights remind us that "the public" should not be considered a monolithic entity in terms of their receptiveness to a social movement. The first insight is the notion of "resonance," which highlights the fact that a collective action frame is most likely to be 
convincing when it resonates with an individual's own experience (Snow and Benford 1988). By extension, it is reasonable to expect that certain collective action frames will align with certain segments of the public but not others (McDonnell, Bail, and Tavory 2017; Snow et al. 1986). The second insight comes from political mediation theory. Political mediation theory argues that a social movement's impact will be a function of its organizational features (such as its tactics) as well as the external environment in which the social movement occurs (such as the political context) (Amenta 2006).

As it stands, movement scholars know relatively little about the extent to which different segments of the population "receive" the different "signals" put out by social movements. In their recent review of this literature, Amenta and coauthors (2010) issued a call for scholars to "take into account nonmovement factors influential in politics and posit interactive effects among movements, their strategies, and political contextual conditions" (pp. 301). The present study is a first step at filling that gap by examining the extent to which the interaction between a social movement's characteristics and bystander characteristics influence public opinion about a given social movement. The first research question we will address in this study concerns the question of how social movement signals and messages are received: how do social movement characteristics impact levels of public support for the movement? Relatedly, we investigate the resonance/political mediation postulate by asking are some social movement characteristics more effective for certain bystanders than others?

A second shortcoming of the prior research on how social movements signals are received relates to the question of tactical efficacy. Many scholars now argue that nondisruptive, nonviolent social movement strategies are the most likely to garner popular support and engender change (e.g. Simpson, Willer, and Feinberg 2018; Feinberg, Willer, and Kovacheff 
2017; King and Smith 2011; Rojas 2006). Yet emergent work suggests that the very perception of which social movements and tactics are considered "disruptive" is rooted in social histories. For instance, Davenport, Soule, and Armstrong (2011) find that Black protests are more likely than white protests to incur a police presence, and that police are more likely to take action including making arrests and using force - at protests with Black attendees than at predominantly white protests. As the authors note, "protesters' race is a critical piece of information that policing agents have at their disposal when deciding how to respond" (pp. 153). Isaac (2008) points out how the Civil Rights movement has since been subjected to revisionist history in which movement leaders' more subversive tactics were edited out of the cultural narrative and collective memory. Contemporary protests involving Blacks are likely to be presented in the media as violent, disorganized riots (Campbell et al. 2004). This all suggests that the very perception of "disruptiveness" of a particular tactic or social movement is subject to perceptual factors such as its members' racial identity. Thus, the third research question of this study asks how do social movement characteristics/bystander characteristics impact how violent the movement is perceived to be? And relatedly, do these perceptions of violence explain part of the effect of social movement characteristics/bystander characteristics on social movement support?

The media plays a central role in the way social movements are represented and, ultimately, understood by the public (Castells 2015). Increasingly, this media representation of social movements occurs in an online milieu, such as the internet, which can in turn prove instrumental for support and mobilization (Bond et al. 2012; González-Bailón et al. 2011; Van Laer and Van Aelst 2010; Diani 2000). In this study, we hone in on the question of how media representations of social movements online generate reactions from the public (see also Lewis, 
Gray, and Meierhenrich 2014). Online environments are inherently micro-interactional (Golder and Macy 2014), and thus provide a window into how exposure to a particular individual member of a social movement can influence an individual bystander. They therefore implore us to consider the "receiver" side of the micromobilization "signal" process (Snow et al. 1986).

In what follows, we discuss three micro-level characteristics of a social movement that prior research suggests are potentially salient when a social movement emits a "signal." Here we draw not only on research from the study of social movements, but also social psychology theories of interpersonal contact and race. We then turn to bystander characteristics, where once again we draw not only on social movements research, but insights from political sociology as well. Finally, we consider what existing work in the movements and collective action literature tells us about how violence impacts social movement support, and what factors may shape the very perception of violence in the first place.

\section{SOCIAL MOVEMENT CHARACTERISTICS}

Although there are undoubtedly many aspects of social movements that may be salient for the public in determining whether or not to support it (cf Fassiotto and Soule 2017; Wouters and Walgrave 2017; Andrews et al. 2016), we focus our attention on two key, micro-level factors that the prior mobilization literature suggests may be relevant for garnering support, sympathy, and outrage for a social movement's cause: emotion and race. Each of these factors leads us to derive a model with a subsequent prediction for how it will influence the public's reception of the social movement's cause.

\section{The Emotion Model}

The expression of emotions is generally seen as a positive force for garnering support and recruiting bystanders to become participants by highlighting injustices that need rectifying 
(Goodwin, Jasper, and Polletta 2009, 2000; Snow, Zurcher, and Eckland-Olson 1980). Research in this area finds that emotions may function as an accelerator, increasing the speed at which support for a social movement translates into action (van Stekelenburg and Klandermans 2013), while "framing" studies such as Gould's (2009) and Nepstad and Smith's (2001) find that activists strategically manage and use anger and moral outrage to encourage bystanders to empathize with and provide material and nonmaterial support.

Studies of emotion and social movements tend to conclude that anger or frustration over injustice is a necessary prerequisite for political mobilization (Flam and King 2005; Aminzade and McAdam 2002; Jasper 1998; Gamson 1992). Researchers in the area of affect similarly conclude that "anger may help mobilize behaviors that are directed toward positive social ends" (Feschbach 1986: 123-4). While early scholars of social movements generally failed to assign any explanatory importance to emotion, recent scholarship has begun to see emotion "not simply as a characteristic feature of emergent collective action, but as a necessary causal component of any explanatory theory" of collective action (McAdam 2017:201). Specific to social movements involving race, Banks (2016) finds that anger plays an important role in motivating whites to take political action regarding affirmative action policies or Confederate-era commemoration. Given how the prior research on social movements and on affect has highlighted the importance of emotion in evoking sympathy and galvanizing people to action, the emotion model thus would predict a social movement member's emotional display - in particular, anger - increases a bystander's support for that movement's cause:

H1: A social movement member's display of emotions influences a bystander's social movement support. 


\section{The Race Model}

Drawing from literature on racism and racial animus, the race model predicts that the race of the protestor will shape bystander support for the movement. Racial prejudice plays a large role in social interactions, both consciously and implicitly. Scholars have documented that, when possible, whites tend select into schools away from Black populations (Goyette 2008; Saporito and Lareau 1999). This same pattern is observed in housing, where researchers find that avoidance of predominantly Black neighborhoods is a prominent mechanism upholding residential segregation (Quillian 2002; Farley et al. 1994). Testing competing hypotheses, Bobo and Zubrinsky (1996) find that residential segregation is best explained by racial prejudice, rather than perceived economic status or in-group preference. Indeed, extensive work on aversive racism demonstrates that white Americans are generally inclined to avoid interactions with minority groups, specifically Blacks, when possible (Pearson, Dovidio, and Gaertner 2009; Dovidio and Gaertner 2004; Gaertner and Dovidio 1986).

Anti-Black sentiment is not always overt and is racial prejudice is sometimes expressed subconsciously. In a study of online dating, Anderson et al. (2014) found that even when users expressed no racial preference in romantic partners, they demonstrated strong same race preferences in their behaviors. Other times, racial prejudice is masked by stereotypical thinking or alternative explanations for racial inequality (Feagin and O'Brien 2004; Bobo, Kluegal, and Smith 1997; Sears et al. 1997). For example, much racial animus is due to negative stereotypes that Black Americans are unwilling to help themselves and therefore undeserving of assistance (Sears and Henry 2003; Virtanen and Huddy 1998). In a meta-analysis on whites' interracial helping behavior covering 31 experiments over 40 years of work, Saucier, Miller, and Doucet (2005) found a stable pattern of discrimination reflective of aversive racism, in which whites 
most often preferred to help other whites. These negative associations and aversive behaviors can have substantial effects on political outcomes. For example, based on previous voting patterns and the density of racially charged Google searches, Stephens-Davidowitz (2014) estimates that anti-Black racial animus cost Barack Obama an estimated 4 percentage points of the national popular vote in both the 2008 and 2012 presidential elections. Based on the extant literature on anti-Black racism, prejudice, and aversion, we expect that Black protestors in particular will be less likely to garner support for their cause.

H2: A social movement member's race influences a bystander's social movement support.

\section{The Racialized Emotion Model}

The racialized emotion model of social movement support builds on the emotion model (H1), but incorporates insights from the literature on emotion and social structure. These literatures suggest that effects of emotional displays may in fact depend on the identity of the person expressing them. For example, Hochschild's $(1983,1979)$ concept of emotion work posits that individuals actively manage their feelings in response to social structure. Specifically, "feeling rules" are the expectations we hold of certain actors to perform particular emotions given their location in social-structural space. In other words, displays of emotion are subject to interpretation, and this interpretation is socially informed. Thus, an actor's emotion is variably interpreted by others depending on the identity of the actor displaying that emotion (Turner and Stets 2005; Thoits 1989).

In particular, the racialized emotion model posits that a social movement member's race interacts with the emotion displayed, based on evidence that emotions are perceived differently depending upon the race of the actor. Schwalbe et al. (2000) argue that, "sustaining a system of inequality, one that generates destabilizing feelings of anger, resentment, sympathy, and despair, 
requires that emotions be managed" (p. 434). Given the extent of documented racial inequalities, one might expect to discover policing of emotional expressions by marginalized groups. Indeed, recently emerging research in the field of sociology of emotion builds upon the concept of "feeling rules" and finds that there are cultural expectations regarding the performance of emotion that are specific to one's race or gender.

For instance, Wingfield (2010) finds that displaying anger, frustration, or annoyance is viewed as inappropriate when a Black worker - particularly a Black man - expresses this emotion. According to Wingfield, a stereotype exists in which "a middle class, educated African American male, who despite his economic and occupational success, perceives racial discrimination everywhere and consequently is enraged" (2007:12). In order to avoid being perceived as the stereotypical angry Black man, these individuals must strenuously adhere to "racialized feeling rules" that prohibit expressions of anger and acknowledgement of race-based inequities (Wingfield 2010). Doan (2016) uses a series of experiments to find that race and gender influence expectations regarding what emotions an individual should display. Examining race, gender, and emotion on college campuses, Wilkins (2012) finds feelings of anger and resentment toward unequal outcomes can be dismissed by others because they are seen as inappropriate in intensity, timing, or for the situation.

The racialized emotion model suggests that Black social movement members may be subject to racialized feeling rules as these expressions may not be seen as "appropriate" displays of emotion (Shields 2005) and that these members are subject to positive or negative sanctions based on the extent to which they are judged to be fulfilling their "appropriate" roles, partially indicated by their displays of emotion (Turner 2007) in line with expectations of their identities (Robinson and Smith-Lovin 1999). The racialized emotion model therefore extends this 
prediction to social movement support by hypothesizing that there is an interaction between a social movement member's race and display of emotion in terms of how this influences ultimate support for the movement's cause.

H3: The effect of a social movement member's display of emotion on a bystander's social movement support will depend on the social movement member's race.

\section{BYSTANDER CHARACTERISTICS}

Once again, there are many bystander-level characteristics that are known predictors of support for and ultimate participation in political movements (Schussman and Soule 2005). Following the insights from resonance/frame alignment theory and political mediation theory, we are primarily concerned with which aspects of bystanders may interact with social movement characteristics. Indeed, we expect that some micro-level social movement features are more or less effective for different bystanders, particularly when it comes to a bystander's political orientation.

\section{The Politicized Emotion Model}

We further build on $\mathrm{H} 1$ (the emotion model) by noting that recent work in political polarization shows strong ideological divisions among Americans. Some scholars argue that these political differences are deeply rooted in psychological differences between those on the Left and those on the Right (Kruglanski 2013; Jost et al. 2003a, 2003b) and that these differences permeate nearly every aspect of our public and private lives (Jost 2006). For example, Lakoff (1997), observing differences in political metaphors, found that whereas conservatives adhere to a "strict father" model of moral discipline, liberals prefer a "nurturing parent." Jost (2006) finds a clear tendency for conservatives to score higher on measures of dogmatism, intolerance of ambiguity, needs for order, structure, and closure, and to be lower in openness to experience and 
integrative complexity than moderates and liberals. Similarly, Carney et al. (2008) conclude that liberals are generally more open-minded in their pursuit of creativity, novelty, and diversity, whereas conservatives tend to pursue lives that are more orderly, conventional, and better organized. On average, conservatives are more likely than liberals to fear crime, terrorism, and death (e.g., Jost et al., 2003a; Wilson, 1973), and to perceive the world as a dangerous place (Altemeyer 1998; Duckitt 2001).

Indeed, scholars have attributed the tendency of conservatives to hold more prejudicial attitudes toward members of deviant or stigmatized groups than liberals at least partially to elevated levels of threat and need for order (Cunningham et al. 2004; Duckitt 2001; Whitley 1999; Altemeyer 1998, 1988; Sidanius et al. 1996; Adorno et al. 1950). Furthermore, findings from work on Moral Foundations Theory finds that liberals and conservatives attend to different affective or moral cues in their environment, such as harm or disgust (Graham, Haidt, and Nosek 2009). Given this literature on the affective roots of political schisms in the contemporary United States, the politicized emotion model predicts that liberal bystanders will be swayed toward social movement support by certain emotion(s), whereas this same emotional display would dissuade a comparable conservative bystander. Moreover, people of different political orientations may find a social movement more or less legitimate and threatening, depending on the emotion conveyed by the movement's members.

H4: The effect of a social movement member's display of emotion on a bystander's social movement support will depend on the bystander's political ideology.

\section{The Politicized Race Model}

The politicized race model builds on the race model (H2), but also recognizes the importance of including a bystander's own political view in the effect of race on social 
movement support. Race is highly politicized in the United States (Luttig, Federico, and Lavine 2017; Omi and Winant 2014; Novkov 2008; Hutchings and Valentino 2004); thus we might expect that a social movement member's racial identity plays a (de)motivating role in soliciting social movement support, depending on a bystander's own political views.

Indeed, there are both theoretical and empirical reasons to expect the race of the social movement participant to affect outcomes differently based on political ideology. Carmines and Stimson (1989) argue that American politics began to polarize around issues of race during the time of the Civil Rights Movement, while Valentino and Sears (2005) highlight racial conservatism as a driving factor in the Southern shift to the Republican Party. While the Democratic Party has voiced support for race-conscious positions, the GOP has employed a "color blind" approach in order to capture the support of white voters anxious about racial change (Olson 2008). Despite the so-called "color blind" approach, scholars argue there remains a "race-conscious policy alliance" (King 2011). Rather than overt racial positions, conservative politicians employ "dog whistles" (Lopez 2015) or appeal to calls for "law and order" (Murakawa 2008) in order to build a base fueled by white backlash to racial and ethnic minorities (Abrajano and Hajnal 2015). Using this coded language enables candidates to activate negative racial stereotypes without violating sentiments of equality or norms of socially acceptable public discourse (Berinsky 1999; Kuklinski et al. 1997a).

Mendelberg (2001) shows the power of such strategies. She demonstrates that when policy issues such as crime are paired with subtle cues, such as a picture of a Black man, heavily racialized opinions and evaluations emerge. In line with previous work, which has demonstrated that liberals and conservatives react differently to primes involving race (Nail, Harton, and 
Decker 2003), the politicized race model predicts that liberals and conservatives will have differing responses to the race of the social movement participant.

H5: The effect of a social movement member's race on a bystander's social movement support will depend on the bystander's political ideology.

\section{PERCEPTIONS OF VIOLENCE}

Research on social movement support finds that extreme tactics or disruptive protests are actually demotivating because they inhibit popular support or decrease likelihood of achieving the movement's goals (Feinberg, Willer, and Kovacheff 2017; King and Smith 2011; Stephan and Chenoweth 2008; Rojas 2007, 2006). Thomas and Louis (2014) found that reports of highly disruptive protest activities, such as those that included reference to violent acts, diminished support for protest groups. Wasow (2017) found that, in the 1960s, areas in which violent civil rights protests occurred saw decreased Democratic vote share among whites, while areas with more nonviolent protests saw an increase in Democratic vote share. Most recently, Simpson, Willer, and Feinberg (2018) found that the use of violence not only led to decreased support for a movement's cause but can also increase support for opposition groups. There is thus strong prior evidence leading us to expect that extreme or violent tactics are demotivating for social movement support. We expect to replicate this finding in the current study:

H6: If bystanders perceive that a social movement event is likely to become violent, they will be less likely to support it.

We will build on this line of work by arguing that whether a social movement is seen as extreme or disruptive depends - at least in part - on how members of that social movement are perceived. In particular, we expect that a social movement member's race influences perceptions 
of violence. We contend that Black participants are more likely to be associated with perceptions of violence.

Indeed, Blackness and violence are linked for many Americans due to cultural influences including television, movies, music, and newspapers provide a constant barrage of information that often depicts Blacks as violent (Cosby 1994; Gray 1989). Public perceptions of crime are highly racialized and the association between Blacks and violent crimes is strong and is perpetuated by the media (Hurwitz and Peffley 1997). According to Quillian and Pager (2001), the percentage of young Black men in a neighborhood is positively associated with perceptions of the neighborhood crime level, even after controlling for multiple measures of crime rates and other neighborhood characteristics. Similarly, research on social disorder finds that people are more likely to perceive neighborhoods to be in a state of disarray when the neighborhood is predominated by Black Americans (Sampson and Raudenbush 2004).

Insights from social psychology highlight the implicit cognitive association individuals often make between weapons and Black Americans (Payne 2001). These associations have dangerous consequences. Using a video game to test "the police officer's dilemma," Correll et al. (2002) put participants in "shoot" or "don't shoot" scenarios and found that participants made the decision to fire on an armed target more quickly when that target was Black, choose not to shoot more quickly when that target was white. Kahn and Davies (2011) corroborate these findings, showing that Blacks are prone to shooter bias and that, in fact, the likelihood of being mistakenly shot increases with darker skin tones. Moreover, these racial stereotypes are readily activated. Kubota and Ito (2014) find that viewing a Black, angry face strengthens the implicit association between Black Americans and violence and Eberhardt et al. (2004) find that simply seeing a Black face triggers racial stereotypes. 
This research all highlights an important point: the very perceptions of extreme tactics, disruptive protests, or social disarray are likely rooted in deeply embedded cultural associations between race and violence or disorder. We therefore expect that the race of the social movement member plays an important role in the likelihood of violence associated with a social movement event such as a protest. ${ }^{2}$ Thus, if support is found for a social movement model that incorporates race (the race model [H2], the racialized emotion model [H3], or the politicized race model [H5]), the racialized perceptions of violence prediction expects that part of any negative impact of viewing a Black participant on social movement support can be explained by the association bystanders make between Blackness and violence.

H7: Bystanders are more likely to perceive that the social movement event will end in violence when they see a Black participant than if they see a white one, and this explains part of the role of race on social movement support.

We depict this potential relationship in the path diagram below, Figure 1. In a social movement model with race, we expect race to have both a direct effect on support, as well as an indirect which flows through perceived violence.

Figure 1. Predicted Mediation Effect of Race on Support Through Perceived Violence

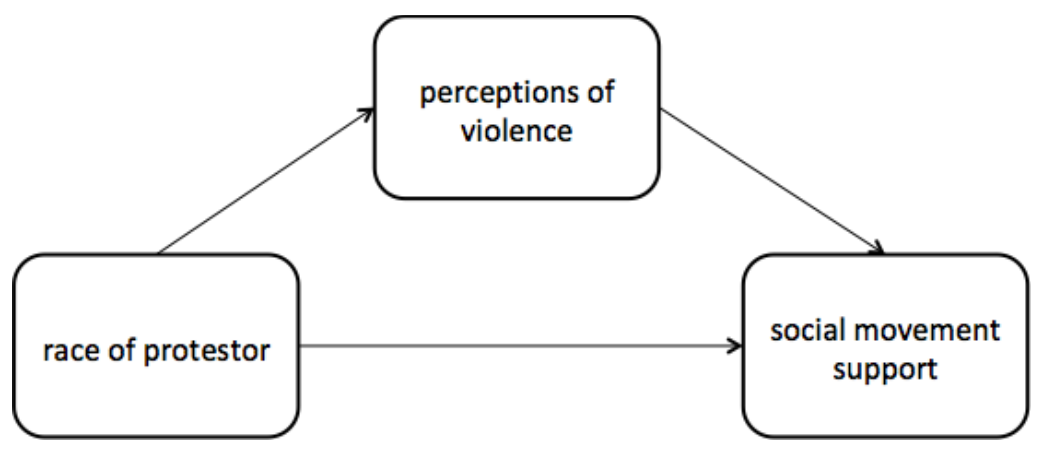




\section{DATA AND METHODS}

To test these hypotheses, we employ a survey experiment, a common technique in political science and used by sociologists who are interested in beliefs and judgments (Gaines, Kuklinski, and Quirk 2006; Jasso 2006). In a survey experiment, participants are presented with randomly assigned manipulations, and their response to the manipulation is measured. In this way, the causal effect of the manipulation on an outcome can be established (Webster and Sell 2007). The present survey experiment has two elements which are manipulated: emotion (neutral versus angry) and race (white versus Black), to create a two-by-two factorial design.

\section{Experimental Manipulation}

The experimental manipulation is four variations of a vignette in which the race and/or emotion of the actor are varied. The vignette is a brief news story about police shootings of unarmed teenagers, and subsequent protests around the nation, ${ }^{3}$ accompanied by a photo of a protestor. The emotion and race of the protestor are the only factors that vary between the four conditions (see Figures A1-A4 in Appendix A); the news story remained identical in all conditions. Pre-testing of the photos ensured that there were no confounding differences across the images such as attractiveness, nor were there any problems with respondents being able to identify the race of the person in the image. ${ }^{4}$

Participants were forced to spend at least 15 seconds reading the news story and observing the photo before they were permitted to advance to the social movement perception and support questions. Once they advanced to these questions, they were not allowed to go back to the news story or photo and were forced instead to rely on their initial impressions.

\section{Outcomes: Measuring Social Movement Support and Perceptions}


Participants were asked about their support for a social movement related to the event, their perceptions of protest, their recall and interpretation of the event and accompanying photo, and their demographic information. To examine support for the social movement, we rely on three kinds of measures: one behavioral, one attitudinal, and one prospective behavioral. ${ }^{5}$ For the behavioral measure of support, respondents were presented with the option of signing a petition in support of the social movement being depicted in the news story (see Appendix B for text of petition). We sought to maximize external validity and believability by using language from an actual Change.org petition. ${ }^{6}$

For the attitudinal measure of support, we asked participants how justified they believed the protestors are in taking this action (response options ranged from $1-5$, where $1=$ "not at all justified in their protest," and $5=$ "completely justified in their protest"). For the prospective behavioral measure of support, we asked how likely participants would be to attend a local rally to support the protestors' cause (response options ranged from 1-5, where $1=$ "I would definitely not attend," and $5=$ "I would definitely attend"). For the perceptual measure (tests of Hypotheses 6 and 7), we asked participants how likely a protest like this one could become violent (response options ranged from 1-5, where 1 = "extremely unlikely" and 5 = "extremely likely").

\section{Sample Source and Quality}

The data for this survey experiment were collected via Amazon's Mechanical Turk (MTurk). Mturk is a data source increasingly used by social scientists for experimental research. Studies of the Mturk data pool have found that its samples are relatively high quality and diverse, similar to those gathered through random-digit dialing and internet survey techniques (Weinberg, Freese, and McElhattan 2014; Goodman, Cryder, and Cheema 2013; Simons and Chabis 2012; Paolacci, Chandler, and Ipeirotis 2010). The analytic sample for this study $(\mathrm{N}=2,821)$ is fairly 
representative of the American population in terms of demographic characteristics (see Table 1 below). Compared to the U.S. population generally, our sample is slightly more male, slightly more white, somewhat less religious, somewhat more educated, similar in terms of income, and somewhat less conservative (see Table A1 in Appendix C for comparison of study sample to U.S. population).

Table 1. Descriptive statistics of study sample

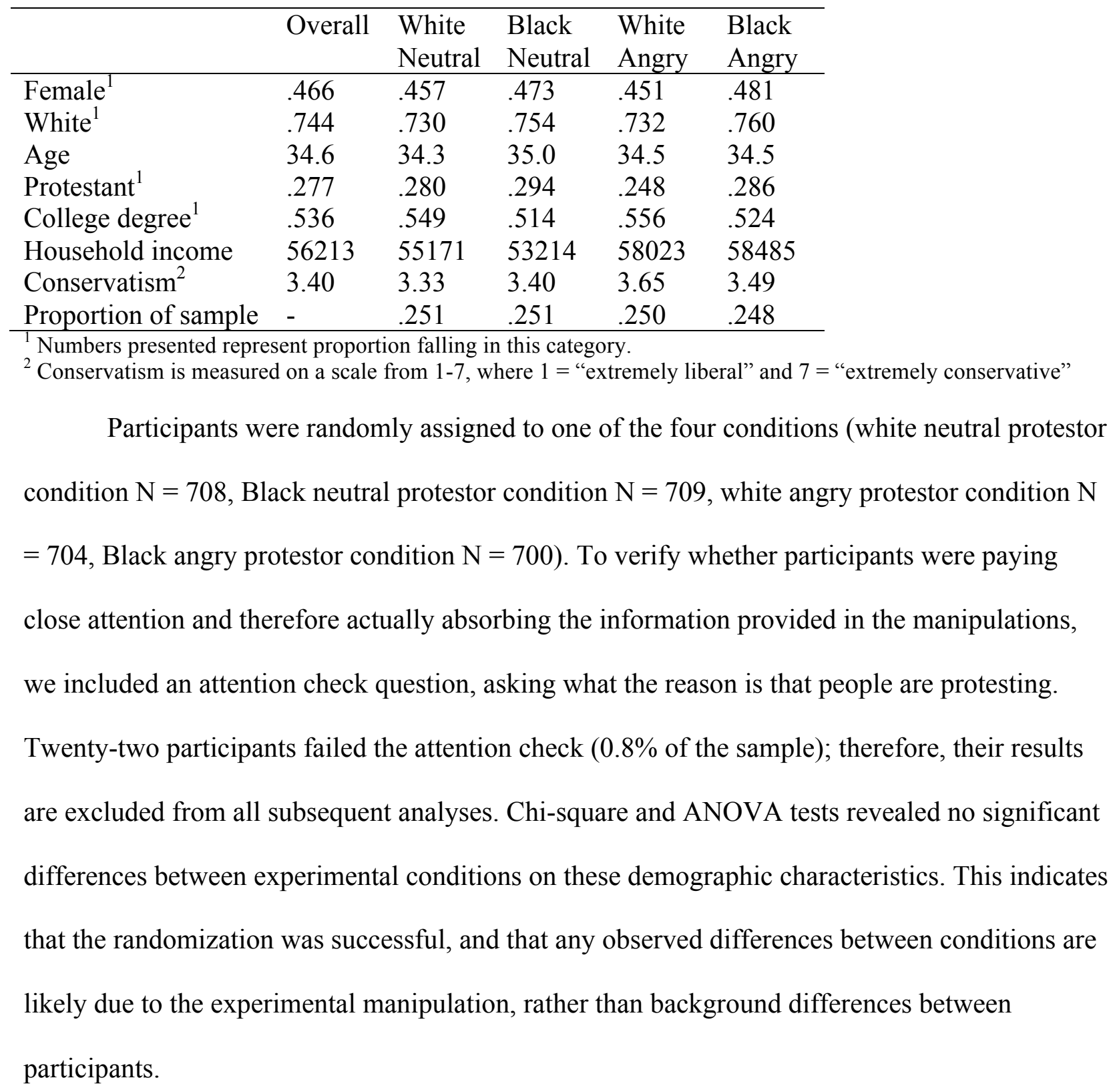




\section{Analytic Approach}

To test the various theorized models of social movement support (Hypotheses 1-5), we modeled each of the three elements of support as a function of the characteristics of the protestor and/or bystander, as implied by each model. Signing the petition is modeled using probit regression; how justified the protestor is, and the likelihood of attending a future rally is modeled using linear regression. ${ }^{7}$ We adjudicate between the hypothesized models (Hypotheses 1-5) by using parsimonious measures of model fit, Akaike's Information Criterion (AIC) and Bayesian Information Criterion (BIC) (Raftery 1995), as well as examining whether there are significant differences between conditions in each model. Once the best-fitting model is selected, we present the results from the experimental manipulations for that model. In order to test the mediating effects of perceived emotion and perceived violence (Hypotheses 6 and 7), we use generalized structural equation modeling to identify the proportion of the total negative/positive impact that each mediator has on the observed effects, with multiple group analysis to account for the potential interaction of bystander political orientation with experimental condition.

\section{RESULTS}

To examine which theorized model best explains social movement support, we begin by assessing model fit statistics for the five possible models across all three measures of social movement support. Table 2 below displays model fit statistics for all of the outcomes. The lowest AIC and BIC values occur for the politicized race model for probability of signing the petition, how justified the protest is, and likelihood of attending a future rally. The BIC differences between the politicized race model and the next best model range from 7 to 12 , indicating 'strong' to 'very strong' evidence that the politicized race model is a better fit than the others (Raftery 1995:138-9). The consistency of results across all three outcomes suggests that 
regardless of how one operationalizes social movement support - using a behavioral measure, an attitudinal measure, or a prospective behavioral measure - the politicized race model best explains social movement support for this vignette, in line with Hypothesis 5: that the race of the protestor matters for social movement support, and this effect depends on a bystander's own political ideology.

Table 2. Model Comparisons for Three Measures of Social Movement Support

\begin{tabular}{|c|c|c|c|c|c|}
\hline Model & Emotion & Race & $\begin{array}{l}\text { Racialized } \\
\text { emotion }\end{array}$ & $\begin{array}{l}\text { Politicized } \\
\text { emotion }\end{array}$ & $\begin{array}{l}\text { Politicized } \\
\text { race }\end{array}$ \\
\hline \multicolumn{6}{|c|}{ Signed Petition } \\
\hline AIC & 2020.968 & 2020.067 & 2024.026 & 1953.261 & 1941.052 \\
\hline $\mathrm{BIC}$ & 2032.387 & 2031.486 & 2046.865 & 1976.1 & 1963.891 \\
\hline LL & -1008.484 & -1008.033 & -1008.013 & -972.6304 & -966.526 \\
\hline $\mathrm{N}$ & 2230 & 2230 & 2230 & 2230 & 2230 \\
\hline \multicolumn{6}{|c|}{ Protest Justified } \\
\hline AIC & 6617.956 & 6617.859 & 6615.295 & 5940.2 & 5933.063 \\
\hline $\mathrm{BIC}$ & 6629.375 & 6629.278 & 6638.134 & 5963.039 & 5955.902 \\
\hline LL & -3306.978 & -3306.929 & -3303.647 & -2966.1 & -2962.531 \\
\hline $\mathrm{N}$ & 2230 & 2230 & 2230 & 2230 & 2230 \\
\hline \multicolumn{6}{|c|}{ Likelihood of Attending Future Rally } \\
\hline AIC & 7027.781 & 7028.527 & 7031.123 & 6627.169 & 6618.496 \\
\hline $\mathrm{BIC}$ & 7039.201 & 7039.946 & 7053.962 & 6650.008 & 6641.335 \\
\hline LL & -3511.89 & -3512.263 & -3511.562 & -3309.584 & -3305.248 \\
\hline $\mathrm{N}$ & 2230 & 2230 & 2230 & 2230 & 2230 \\
\hline
\end{tabular}

NOTE: Smaller values of AIC and BIC are preferred. Best-fitting model for each measure is in bold.

\section{Effect of Social Movement \& Bystander Characteristics on Support}

We begin by briefly describing the patterns of findings for the four models that do not fit the data as well as the politicized race model. For the emotion model, we find no differences between the "angry" and "neutral" conditions for any of the three outcomes. We see a similar pattern for the race model: there are no significant differences between the Black and white condition in terms of support. When looking at the racialized emotion model, we find that Black angry protesters did cause bystanders to perceive the protest as less justified compared to both Black neutral protestors $(\mathrm{p}=.012)$ and white angry protestors $(\mathrm{p}=.012)$, yet there was no 
significant difference between any of the Black angry/white angry/Black neutral/white neutral protestors on the other two measures. Finally, the politicized emotion model results demonstrate that the effect of seeing an angry protester did not significantly differ between conservatives and liberals for any of the three types of support. Overall, results from the emotion model, race model, and racialized emotion model reveal few differences between conditions.

We next present results from the politicized race model for each of the three outcome measures. This model specified a different effect of protestor's race on social movement support depending on whether the bystander is a liberal or a conservative. ${ }^{8}$ Figure 2 below shows the probability of signing a petition across protestor's race, by political ideology.

Figure 2. Likelihood of Signing Petition

\section{Likelihood of Signing Petition}

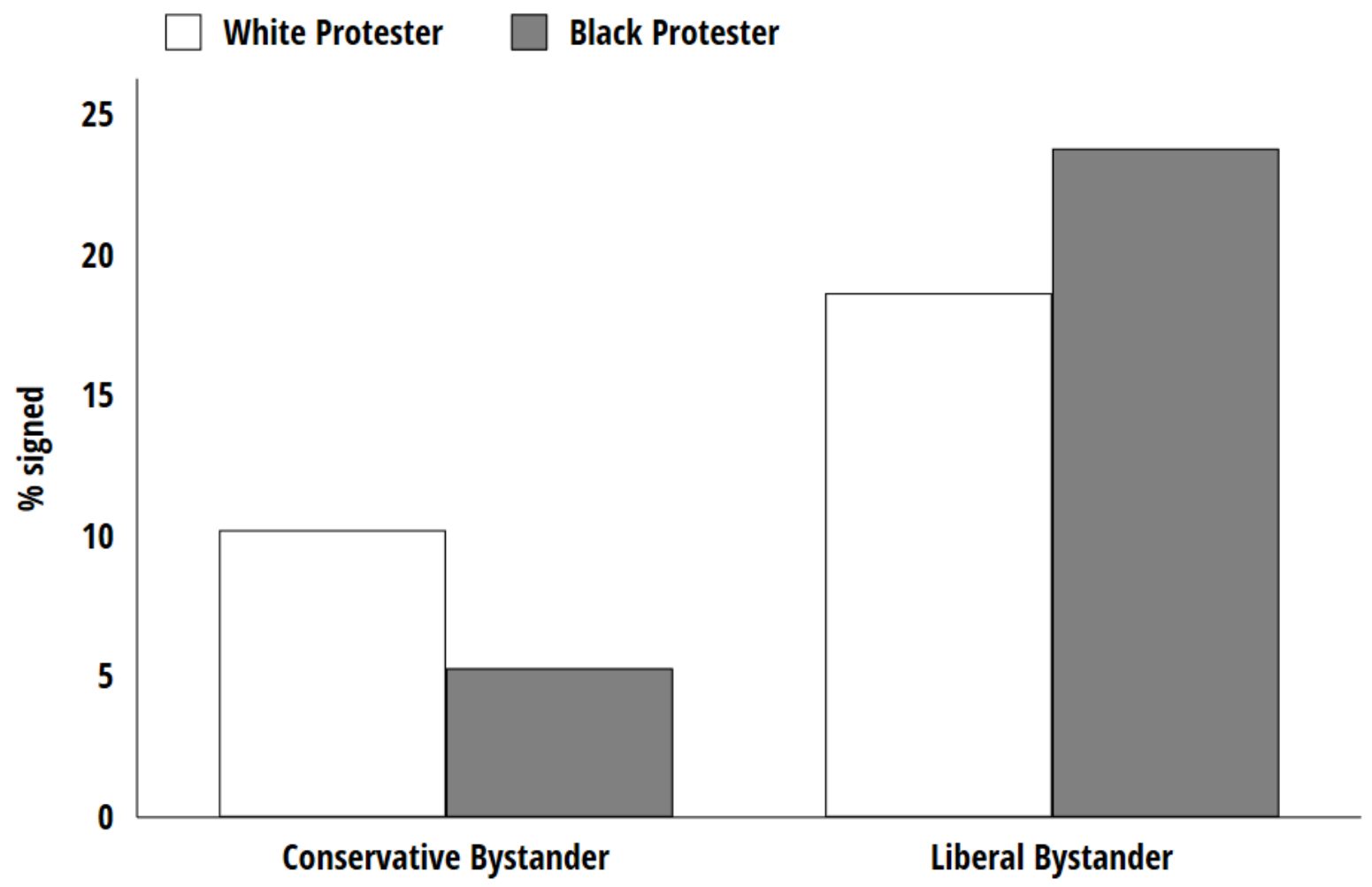


The effect of a protestor's race on likelihood of signing the petition is statistically significant for both conservatives and liberals, though the effects go in opposite directions. For conservatives, viewing a Black protestor decreases likelihood of signing the petition relative to seeing a white protestor: $10 \%$ of conservatives signed the petition when the news story contained an image of a white protestor, whereas only $5 \%$ signed when the news story depicted a Black protestor $\left(X^{2}=6.02, \mathrm{p}=.014\right)$. Among liberals, the pattern is reversed: $19 \%$ signed when the news story was accompanied by an image of a white protestor, compared to $24 \%$ of liberals who signed the petition when seeing a Black image $\left(X^{2}=5.91, \mathrm{p}=.015\right)$. Unsurprisingly, the difference in effects of protestor's race between conservatives and liberals is statistically significant $\left(X^{2}=10.39, \mathrm{p}=.001\right)$. We next examine the attitudinal outcome, how justified the protest is judged to be, in Figure 3 below. 
Figure 3. Protest Justified

\section{Believes the Protest is Justified}

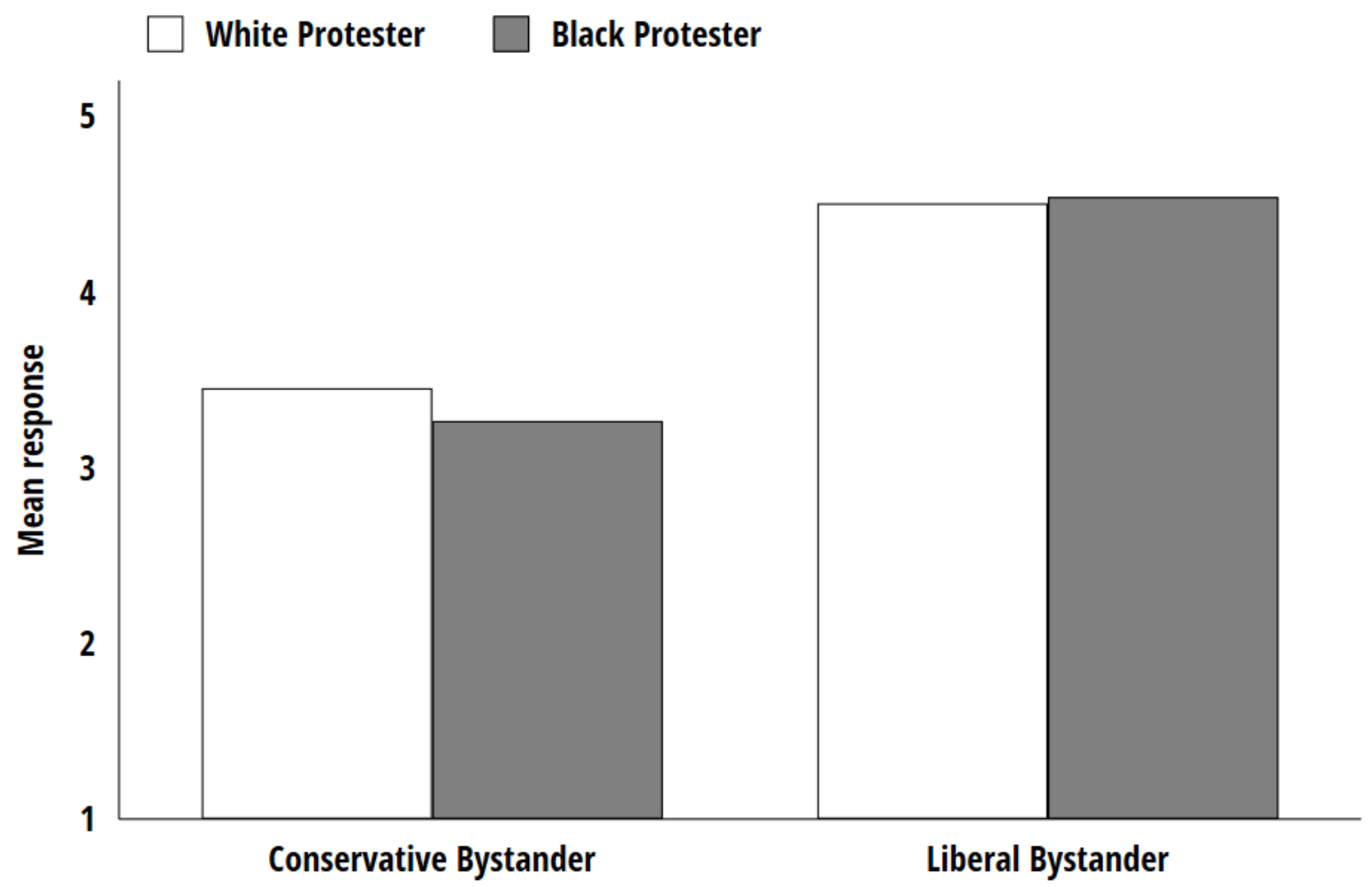

Reading a news story with a photograph of a Black protestor leads conservative respondents to see the protest as less justified than when they read a news story with a photograph of a white protestor $(\mathrm{F}=7.58, \mathrm{p}=.006)$. Conservative respondents rated the justification of the protest with a mean score of 3.455 when seeing the white protestor, versus 3.268 when seeing the Black protestor. This corresponds to a .175 standard deviation penalty among conservatives for the Black protestor in terms of how justified the protest is judged to be. By contrast, the race of the protestor makes no significant difference in how justified liberals rate the protest $(\mathrm{F}=0.59, \mathrm{p}=.441)$. They rated the protest as a 4.508 in terms of justification, on average, when the story's image included a white protestor, versus an average rating of 4.544 
when the story's image included a Black protestor, a "boost” for Black protestors of .036 standard deviations which we cannot conclude as statistically different from 0 . However, the formal test shows that the difference between these effects is statistically significant $(\mathrm{F}=7.29, \mathrm{p}$ $=.007)$, consonant with the politicized race model's prediction. Lastly, we turn to the prospective behavioral outcome, how likely respondents say they would be to attend a similar rally, in Figure 4.

Figure 4. Likelihood of Attending a Protest

\section{Likelihood of Attending a Protest}

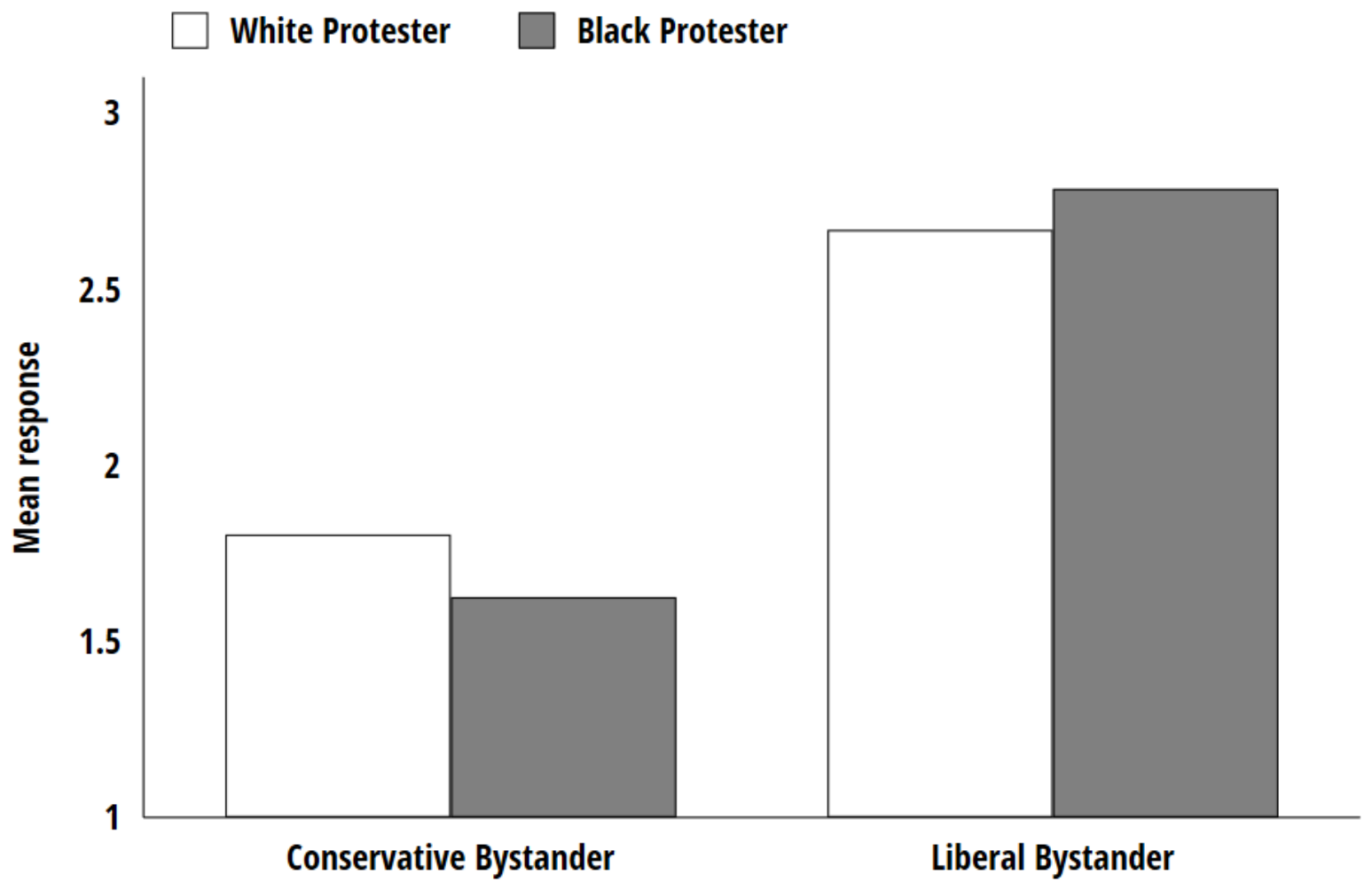

For self-reported likelihood of attending a similar rally to the one mentioned in the news story (rated on a Likert scale that ranges from 1 to 5), we observe that the race of the protestor impacts both conservatives $(F=5.07, \mathrm{p}=.024)$ and liberals $(\mathrm{F}=4.49, \mathrm{p}=.034)$. For 
conservatives, seeing a Black protestor decreases the likelihood a respondent reports they will attend a similar rally, shifting the mean likelihood of attending from 1.804 for the white protestor to 1.630 for the Black protestor. This represents a .152 standard deviation penalty for the Black protestor image among conservatives in terms of prospective attendance at a similar protest event. For liberals, seeing a Black protestor alongside the news story increases the likelihood a respondent reports they will attend a similar rally from 2.670 for the white protestor image up to 2.786 for the Black protestor image. This represents a .100 standard deviation boost in social movement support for the Black protestor among liberals. Once again, the Wald test finds that the difference in these two effects is statistically significant $(\mathrm{F}=9.36, \mathrm{p}=.002) .{ }^{9}$

To summarize the results thus far, our experimental findings are consistent with the politicized race model: the three measures of social movement support show starkly different effects of a protestor's race for liberal bystanders and conservative bystanders. Liberals' social movement support was significantly enhanced when seeing a Black protestor relative to a white one, and conservatives' social movement support was significantly depressed when seeing a Black protestor as opposed to a white protestor.

\section{Perceptions of Violence and their Role in Explaining Social Movement Support}

We now turn to the role of perceived violence on social movement support. We begin by testing Hypothesis 6: that expecting the protest to end violently impedes social movement support. Table 3 below demonstrates that perceived violence has a significant, negative impact on all three measures of support, precisely as we expected.

Table 3. Effect of Perceived Violence on Social Movement Support

\begin{tabular}{cccc}
\hline & Sign petition $^{\mathrm{a}}$ & Protest justified $^{\mathrm{b}}$ & Attend rally $^{\mathrm{b}}$ \\
\hline $\begin{array}{c}\text { Perceived } \\
\text { violence }\end{array}$ & $-.170 * * *(.028)$ & $-.349 * * *(.018)$ & $-.310^{* * *}(.018)$ \\
Constant & $-1.030 * * *(.029)$ & - & - \\
\hline
\end{tabular}


NOTE: $\mathrm{N}=2,821 . * \mathrm{p}<.05 * * \mathrm{p}<.01 * * * \mathrm{p}<.001$ (two-tailed tests). ${ }^{\mathrm{a}} \mathrm{Z}$-scores of the latent variable (probit) shown. ${ }^{\mathrm{b}}$ Fully standardized OLS coefficients shown.

To what extent does this effect depend on a person's political views? Figure 5 depicts these effects for conservatives and liberals separately. We see that the impact of violence on social movement support is much larger for conservatives in terms of likelihood of signing the petition $\left(X^{2}=46.35, \mathrm{p}<.001\right)$, seeing the protest as justified $\left(X^{2}=612.95, \mathrm{p}<.001\right)$, and chances of attending a future rally $\left(X^{2}=283.74, \mathrm{p}<.001\right)$. Thus, perceived violence plays a much larger role in conservatives' decision to support a social movement's cause than it does liberals'.

Figure 5. Effect of Perceptions of Violence by Political Views

\section{Effect of Perceptions of Violence}

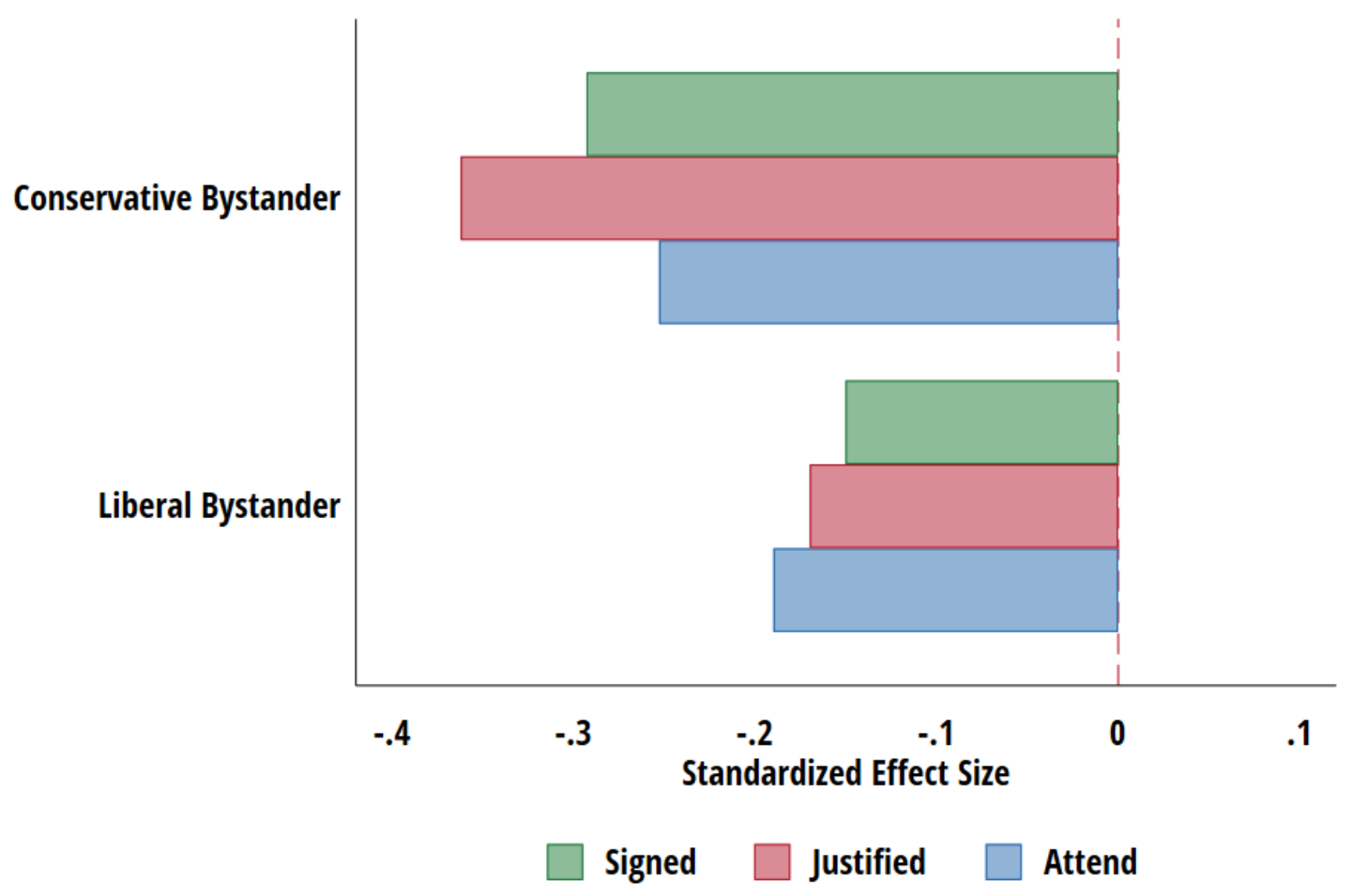

To what extent are these perceptions of violence racialized? Figure 6 below reveals that exposure to a Black protestor is significantly more likely to lead to the belief that the protest will end in violence than exposure to a white protestor $(\mathrm{F}=13.14, \mathrm{p}<.001)$. However, the effect has 
a similar magnitude for conservatives and liberals, and thus we cannot conclude that racialized perceptions of violence vary between political groups $(\mathrm{F}=0.55, \mathrm{p}=.457)$.

Figure 6. Perceptions of Violence by Protestor Race

\section{Likelihood the Protest Will End in Violence}

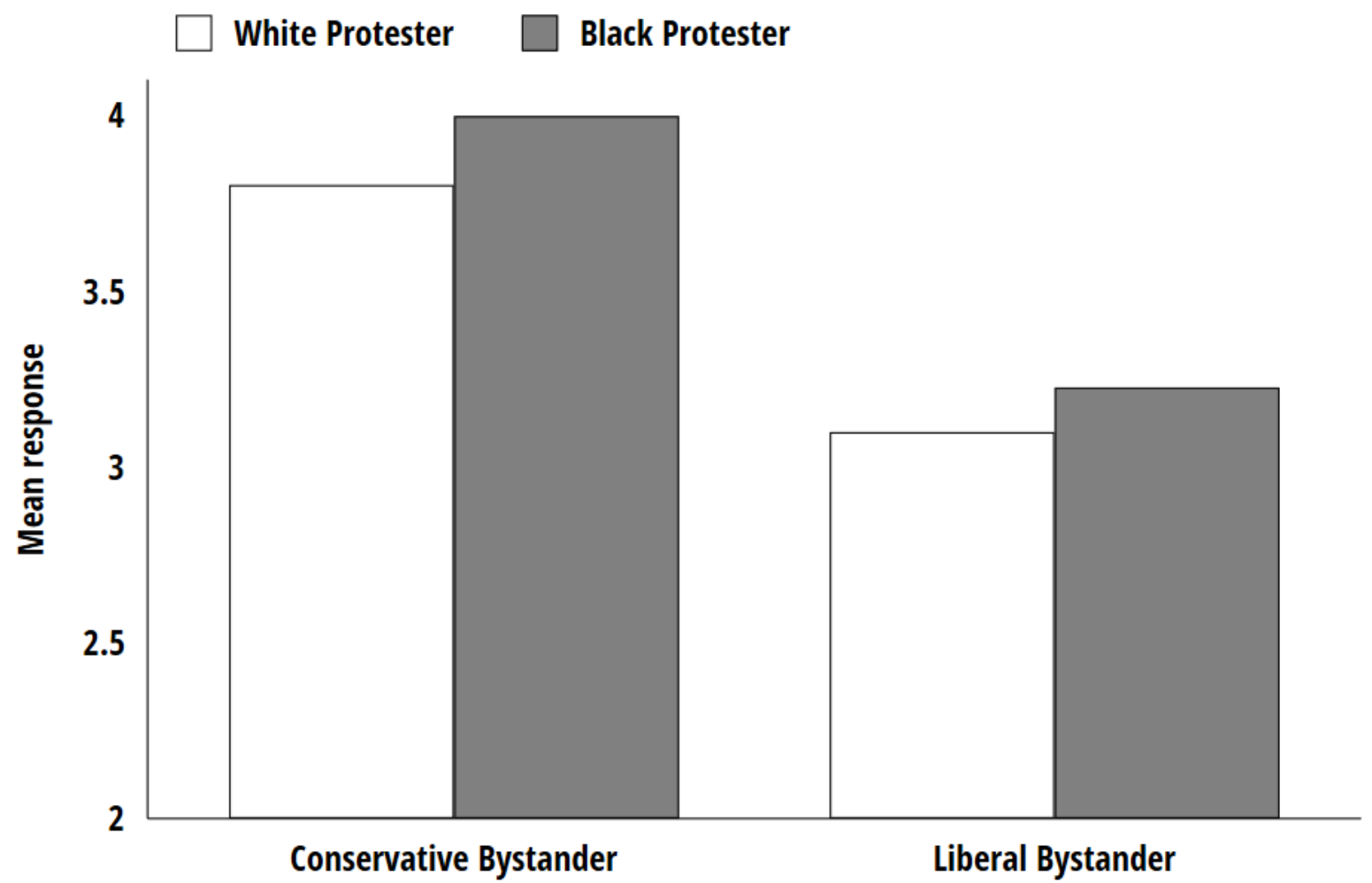

Hypothesis 7 predicted that perceptions of violence explain some of the effect of race on social movement support. To begin, we examine the viability of the politicized race model in this mediation framework by formally testing whether a multiple group analysis is warranted (Acock 2013). Likelihood-ratio tests of constrained pathways (in essence, a race model) versus unconstrained pathways (the politicized race model) support the unconstrained specification for all three outcomes (sign petition $X^{2}=302.26, \mathrm{p}<.001$, protest justified $X^{2}=1021.4, \mathrm{p}<.001$, attend rally $\left.X^{2}=559.12, \mathrm{p}<.001\right)$. We therefore present results separately for conservatives and 
liberals to assess the extent to which racialized perceptions of violence mediate social movement support. Table 4 below depicts these effects for conservatives.

Table 4. Role of Perceived Violence in Effect of Black Protestor on Social Movement Support for Conservatives

\begin{tabular}{cllllll}
\hline & \multicolumn{2}{c}{ Sign petition } & \multicolumn{2}{c}{ Protest justified } & \multicolumn{2}{c}{ Attend rally } \\
\hline & $\begin{array}{l}\text { Probit } \\
\text { coefficient }\end{array}$ & $\begin{array}{l}\text { \% of } \\
\text { effect } \\
\text { explained }\end{array}$ & $\begin{array}{l}\text { OLS } \\
\text { coefficient }\end{array}$ & $\begin{array}{l}\text { \% of } \\
\text { effect } \\
\text { explained }\end{array}$ & $\begin{array}{l}\text { OLS } \\
\text { coefficient }\end{array}$ & $\begin{array}{l}\% \text { of } \\
\text { effect } \\
\text { explained }\end{array}$ \\
\hline Total & $-.346^{*}$ & $10.2 \%$ & $-.187^{*}$ & $39.0 \%$ & $-.178^{* *}$ & $27.5 \%$ \\
effect & $(.152)$ & & $(.082)$ & & $(.068)$ & \\
Direct & $-.311^{*}$ & & -.114 & & $-.129+$ & \\
effect & $(.149)$ & & $(.077)$ & & $(.067)$ & \\
Indirect & $-.035^{*}$ & & $-.073^{* *}$ & & $-.049^{*}$ & \\
effect & $(.017)$ & & $(.027)$ & & $(.021)$ & \\
\hline
\end{tabular}

NOTE: $\mathrm{N}=729$. Standard errors are produced from bootstrapped estimates of 200 replications. Reference category is white protestor. $+\mathrm{p}<.10 * \mathrm{p}<.05 * * \mathrm{p}<.01 * * * \mathrm{p}<.001$ (two-tailed tests). $\%$ of effect explained = (indirect effect / total effect).

For conservatives, reading a news story with a Black protestor's image has a negative impact, and the association between Blackness and perceived violence works to explain part of that effect. $10.2 \%$ of the total negative effect of seeing a Black protestor on probability of signing the petition can be attributed to perceiving that the Black protestor will lead to violence. In terms of the impact of seeing a Black protestor on how justified the protest is deemed to be, $39.0 \%$ of the total negative effect can be attributed to perceiving that the Black protestor will lead to violence. In fact, the direct effect of viewing a Black protestor on judging the protest to be justified drops below conventional significance once the indirect effect of Black through violence is modeled, suggesting that the association between the Black protestor and violence is particularly important for explaining conservatives' lack of social movement support by this measure. Lastly, $27.5 \%$ of the total negative effect of seeing a Black protestor on likelihood of attending a similar rally can be attributed to perceiving that the Black protestor will lead to violence. 
We next explore the potentially mediating impact of racialized perceptions of violence for liberals. Results in Table 5 below demonstrate evidence of a suppressor effect: expecting the protest to end in violence when seeing a Black protestor has a dampening effect on the otherwise-positive effect of being exposed to a Black protestor's image for liberals. This is further evidenced in the diminished size of the total effect compared to the direct effect in all three outcome measures.

Table 5. Role of Perceived Violence in Effect of Black Protestor on Social Movement Support for Liberals

\begin{tabular}{cllllll}
\hline & \multicolumn{2}{c}{ Sign petition } & \multicolumn{2}{c}{ Protest justified } & \multicolumn{2}{c}{ Attend rally } \\
\hline & $\begin{array}{l}\text { Probit } \\
\text { coefficient }\end{array}$ & $\begin{array}{l}\text { \% of } \\
\text { effect } \\
\text { inhibited }\end{array}$ & $\begin{array}{l}\text { OLS } \\
\text { coefficient }\end{array}$ & $\begin{array}{l}\text { \% of } \\
\text { effect } \\
\text { inhibited }\end{array}$ & $\begin{array}{l}\text { OLS } \\
\text { coefficient }\end{array}$ & $\begin{array}{l}\% \text { of } \\
\text { effect } \\
\text { inhibited }\end{array}$ \\
\hline Total & $.177^{*}$ & $7.1 \%$ & .036 & $33.3 \%$ & $.117^{*}$ & $17.6 \%$ \\
effect & $(.078)$ & & $(.041)$ & & $(.053)$ & \\
Direct & $.191^{*}$ & & .054 & & $.142^{* *}$ & \\
effect & $(.078)$ & & $(.039)$ & & $(.053)$ & \\
Indirect & $-.014+$ & $-.018^{*}$ & & $-.025^{*}$ & \\
effect & $(.008)$ & & $(.008)$ & & $(.011)$ & \\
\hline
\end{tabular}

NOTE: $\mathrm{N}=1,501$. Standard errors are produced from bootstrapped estimates of 200 replications. Reference category is white protestor. $+\mathrm{p}<.10 * \mathrm{p}<.05 * * \mathrm{p}<.01 * * * \mathrm{p}<.001$ (two-tailed tests). \% of effect inhibited $=1$ - (total effect / direct effect).

For liberals, $7.1 \%$ of the total positive effect of seeing a Black protestor on probability of signing the petition is inhibited by the perception that the Black protestor will lead to violence. In terms of the role of viewing a Black protestor on the impact of considering the protest justified, $33.3 \%$ of the total positive effect is inhibited by the perception that the Black protestor will lead to violence. In fact, the weakly positive direct effect of seeing a Black protestor on judging the protest to be justified is offset by a small but significant negative indirect effect of seeing the Black protestor through the perceived violence effect. Finally, 17.6\% of the total positive effect of seeing a Black protestor on likelihood of attending a future rally is inhibited by the perception that the Black protestor will lead to violence. 
To summarize the results concerning perceptions of violence and their role in explaining social movement support, we found that perceived violence does impede social movement support. However, these perceptions are shaped by two important factors. Conservatives are far more likely than liberals to be dissuaded from supporting a cause as a result of this perceived violence. Black protestors are much more likely to lead to the perception that the protest will end violently than will white protestors. Our mediation analyses revealed that perceived violence associated with a Black face explains an important part of the negative impact of seeing a Black protestor on social movement support, and this was particularly the case for conservatives. Our predicted path diagram (Figure 1) was indeed correct. For conservatives, this perception of violence that is linked to Blackness explains some of the net negative effect of seeing a Black protestor on social movement support. For liberals, this racialized perception of violence takes the form of a suppressor effect, inhibiting part of an otherwise-positive effect of viewing a Black protestor on the three measures of support. For both conservatives and liberals, the association between the Black image and violence seems to play an especially important role in the neutral (for liberals) or negative (for conservatives) impact of the Black protestor on how justified the protest is deemed to be. For conservatives, we see that perceptions concerning the Black protestor explain why this political group is particularly dissuaded from future rally attendance when they see a Black protestor, whereas liberals' future rally attendance is much less determined by racialized perceptions of violence.

\section{DISCUSSION AND CONCLUSIONS}

This study is part of a burgeoning line of work that seeks to shift the analytic focus from understanding how social movements frame their message to understanding how social movements' messages are received by the broader public. We tested five models of social 
movement support that we hypothesized may be operating in a micromobilization context such as an online media depiction of a protest. Using a survey experiment, we provided bystanders with three potential ways of showing their support for a movement's cause: an observed behavior, an attitude, and a prospective behavior. Our results provided strong support for the politicized race model which hypothesized an interaction between a social movement member's race and a bystander's political views. We found that conservatives are more dissuaded from supporting the cause when reading a news story about a protest that includes a photograph of a Black protestor as opposed to a white one, whereas liberals are more persuaded by a Black protestor relative to a white one.

Our findings reiterate the framework put forth by resonance and political mediation scholars (McDonell et al. 2017; Amenta et al. 2010; Amenta 2006; Snow and Benford 1988; Snow et al. 1986). In fact, although the race model initially revealed no effect of protestor race on social movement support, the politicized race model demonstrates that the seeming lack of effect was due to countervailing patterns among conservative bystanders and liberal bystanders. These heterogeneous effects highlight the importance of taking seriously resonance and political mediation's postulate that social movements' frames may resonate with certain people and not others, and that the efficacy of these signals depends upon the political context in which they are received. Indeed, the present political context of the U.S. is one which is highly politically polarized, particularly around issues of race (Valentino and Sears 2005; Carmines and Stimson 1989).

We also tested the extent to which social movement characteristics and bystander characteristics shape perceptions of violence related to the movement. While most prior work has assumed that violent tactics lead to lower support - a finding which we replicate here -, our 
study is among the first to test which factors shape this very perception of social movementrelated violence. We found that conservatives in particular are deterred from supporting a social movement by their expectation that it will entail violence. Moreover, we found that exposure to a Black social movement member leads to a greater expectation among bystanders that the protest will end violently, regardless of one's political ideology. Racialized perceptions of violence explained an important part of conservatives' hesitancy to support a movement picturing a Black protestor. Meanwhile, liberals would be even more supportive of Black-depicted social movements, were it not for their racialized perceptions of violence. Nevertheless, the boost enjoyed by Black protestors relative to white ones outweighs this racialized violence effect for liberals' likelihood of signing the petition and attending a future rally.

It seems that conservatives' greater expectation of the protest ending in violence could explain why they are less likely to plan to attend a future social movement event when seeing a Black participant: perhaps their perceived violence is related to fear of bodily harm at such an event. However, this explanation is tempered by the fact that the association between Blackness and violence also explains part of why conservatives are less likely to sign the petition when reading a news story with a Black social movement member and are less likely to see the protest as justified. These dynamics suggest that it is not merely a fear of bodily harm that keeps conservatives from participating in the social movement, but that it is also an avoidance of any social movement in which Black people are participants - regardless of whether participation involves in-person or offline modes of support.

This study has important implications for the social movement literature. As we did not find support for a model that included emotion, our findings go against the notion that social movements convince bystanders to join their cause by expressing grievances through emotional 
displays. Nevertheless, it may be possible that expression of emotions - anger in particular - is important for promoting sympathy, empathy, and solidarity within the ranks of the movement's existing members. The impact of emotion across this member/bystander distinction is an opportunity for future work. From a methodological perspective, this study is part of a growing trend of research employing experimental methods to study social movements (see also Simpson et al. 2018; Feinberg et al. 2017). Experimental approaches are particularly useful for testing the dynamics that other researchers have uncovered using case studies or observational data.

Experiments such as this one allow us to test the causal efficacy of social movement strategies in an isolated way, and to assess their relative potential in garnering public support.

The present study also has important implications for the political polarization and race literatures. The diverging impact of the Black protestor's photograph for liberals and conservatives on social movement support represents yet another way that contemporary Americans appear to view - and react to - public phenomena in strikingly different ways. Our findings, however, suggest that this divergence - at least regarding the political event at the heart of this case study - is more rooted in race than affect. Furthermore, we witness racial inequality in a new domain: political support. This inequality presents as a boost for Black social movement participants among liberals, and a penalty for Black participants among conservatives. We also find that the cultural association between Blackness and violence extends beyond neighborhoods and schools and applies to social movements as well.

The effects we observe in this experiment are relatively modest in size. Nonetheless, it is quite striking that merely being exposed to a photograph of a different-raced protestor in an otherwise identical news story for a few seconds can yield divergent levels of social movement support and entirely different perceptions of the protest. We would therefore expect that further 
exposure to depictions of social movement participants - longer duration of exposure (e.g. media segments, full news stories with multiple photographs), different kinds of exposure (e.g. inperson or online interaction with actual social movement participants) - will produce even more pronounced effects than those we witnessed here.

Several features of this study limit its conclusions and generalizability. For one, the vignette we used to present the news story involved a protest around "police departments' use of force." Although the news story never mentioned race, it is likely that this particular political event evoked racialized assumptions pertaining to this issue in the minds of the respondents. Future work should expand the scope of social movements to other domains. Perhaps the politicized race model applies to the case study here because Black people are often perceived as the victims of the very issue which sparked the movement. Further studies may require us to broaden our conclusions to a more abstract model in which certain bystanders are most likely to be persuaded to join a social movement when the visible protestors are those most affected by the issue. Second, the study's sample is not a representative sample of all Americans. While this does not threaten the experimental validity of the manipulations' impacts on the observed outcomes, it does suggest that the size of the differences between liberals and conservatives may not be wholly accurate. If anything, we expect that our estimates given here may understate these differences. Indeed, conservatives are underrepresented on Mturk - and in our sample -, and we expect that social conservatives in particular are underrepresented on Mturk - in our sample religious respondents were particularly underrepresented. A future study using nationally representative data would provide more precise estimates of the exact difference in the race effects for social movement support and perceptions between liberals and conservatives. 
Further work in this area should incorporate additional features of social movement members' identities to understand these potential impacts on social movement support and perceptions of the movement. In particular, we wonder to what extent the dynamics we observed are specific to social movement members who are white and black men. Does the gender of the participant - and potentially other identities, such as sexuality or religion, or other racial groups beyond the Black/white dichotomy - intersect to further inhibit or enhance social movement support (Mirchandani 2003)? Given the additional pressure placed upon Black women to combat racial injustice (Wilkins 2012), we believe the incorporation of gender is key to relevant future work in this area.

In this sociopolitical era in which social movements are forming around racial issues such as the Black Lives Matter movement - understanding how various factors influence bystanders' support of social movements and their public reception becomes increasingly important. This study is the first step in a program that aims to examine how sociodemographic characteristics combine with other known factors to influence how people perceive and contribute to political movements. This work is a clarion call to social movement scholars to acknowledge that perceptions of social movement members - including associations of violence - may play an important role in whether a bystander decides to support or join the movement. Moreover, this study contributes to the social movements and race literatures by reinforcing the notion that perceptions of "extreme" or "disruptive" tactics - such as violence - are rooted in oftimplicit associations related to race.

Our intent with this work is not to further police the comportment of social movement members (see Obasogie and Newman 2016), but rather, to turn the lens on the potential supporters of the social movement and the broader context in which these messages are received. 
The present study highlights how depictions of social movement participants activate particular stereotypes within certain segments of the population. Our hope is that experimental work such as this will further expose the latent cultural perceptions and associations that draw people toward or deter them from social movements. By revealing these biases, our aim is that bystanders will better interrogate their own assumptions as they decide whether to support a social movement's cause and that researchers will incorporate awareness of these biases into a more complex understanding of how social movements garner support. 


\section{NOTES}

${ }^{1}$ Marby and Kiecoly (2005) find that Blacks Americans neither feel nor express more anger than whites, despite a lower average sense of control and higher mistrust.

${ }^{2}$ In fact, whether a social movement event is labeled as a "protest" or a "riot" may depend among other things - on the race of the participants depicted in it (see also Jeffries, Turner, and Morris 1971).

${ }^{3}$ The news story makes no mention of race or emotion involved in the protests or the inciting incidents leading to the protests. Thus, any association participants make regarding race or emotion comes purely from the photo accompanying it.

${ }^{4}$ Facial Action Coding System (FACS) coding by outside researchers who were blind to our hypotheses indicated that the two models' faces did not substantively differ in how angry they appeared to be. FACS involves coding an individual's muscle movements as they change from a baseline (neutral) state to an expression of emotion; thus it is relatively immune to racialized perceptions of emotion (see Ekman and Rosenberg 1997).

${ }^{5}$ Using behavioral measures as outcomes has been shown to combat the potential problem of social desirability bias which is well known in social science research that aims to uncover racial attitudes and behavior (Krumpal 2013).

${ }^{6}$ No actual information was retained from this petition-signing procedure. During debriefing at the end of the experiment, participants were informed that they had not actually signed a petition.

${ }^{7}$ Model fit results lead to the same conclusion when these latter two measures are modeled using ordered logistic regression rather than linear regression: politicized race is the best-fitting model. 
${ }^{8}$ All models excluded respondents who identify as "moderate" in their political views $(\mathrm{N}=586)$, since model comparisons using AIC and BIC require identical estimation samples. Experimental results including moderates are presented in Appendix D.

${ }^{9}$ We also conducted analyses using the politicized race model in which we exclude all Black participants in the experiments since they are more likely to identify as liberal than conservative. Results that exclude Black participants do not substantively different results from those presented here, suggesting that the politicized race effects we observe are not merely attributable to racial in-group effects (see Appendix E). 


\section{REFERENCES}

Abrajano, Marisa and Zoltan L. Hajnal. 2015. White Backlash: Immigration, Race, and American Politics. Princeton, NJ: Princeton University Press.

Acock, Alan C. 2013. Discovering Structural Equation Modeling Using Stata. New York, NY: Stata Press.

Adorno, Theodor W., Else Frenkel-Brunswik, Daniel Levinson, and Nevitt Sanford. 1950. The Authoritarian Personality. New York, NY: Harper \& Brothers.

Altemeyer, Bob. 1988. Enemies of Freedom: Understanding Right-Wing Authoritarianism. San Francisco, CA: Jossey-Bass.

Altemeyer, Bob. 1998. "The Other "Authoritarian Personality." Advances in Experimental Social Psychology 30:47-92.

Amenta, Edwin. 2006. When Movements Matter: The Townsend Plan and the Rise of Social Security. Princeton, NJ: Princeton University Press.

Amenta, Edwin, Neal Caren, Elizabeth Chiarello, and Yang Su. 2010. "The Political Consequences of Social Movements." Annual Review of Sociology 36:287-307.

Aminzade, Ron and Doug McAdam. 2002. "Emotions and Contentious Politics." Mobilization: An International Quarterly 7(2):107-9.

Anderson, Ashtom, Sharad Goel, Gregory Huber, Neil Malhotra, and Duncan J. Watts. 2014. "Political Ideology and Racial Preferences in Online Dating." Sociological Science 1:28-40.

Andrews, Kenneth T., Kraig Beyerlein, and Tuneka Tucker Farnum. 2016. "The Legitimacy of Protest: Explaining White Southerners' Attitudes Toward the Civil Rights Movements." Social Forces 94(3):1021-1044.

Banks, Antoine J. 2016. Anger and Racial Politics: The Emotional Foundation of Racial Attitudes in America. New York, NY: Cambridge University Press.

Benford, Robert D. 1987. "Framing Activity, Meaning, and Social-Movement Participation: The Nuclear-Disarmament Movement." Ph.D, University of Texas.

Benford, Robert D. and David A. Snow. 2000. "Framing Processes and Social Movements: An Overview and Assessment." Annual Review of Sociology 26(1):611-39.

Bobo, Lawrence, James R. Kluegel, and Ryan A. Smith. 1997. "Laissez-Faire Racism: The Crystallization of a Kinder, Gentler, Antiblack Ideology." Pp. 15-42 in Racial Attitudes in the 1990's: Continuity and Change, edited by Steven A. Tuch and Jack K. Martin. Westport, CT: Praeger.

Bobo, Lawrence and Camille L. Zubrinsky. 1996. "Attitudes on Residential Integration: Perceived Status Differences, Mere in-Group Preference, or Racial Prejudice?” Social Forces 74(3):883-909.

Burstein, Paul. 1985. Discrimination, Jobs, and Politics. Chicago, IL: University of Chicago Press. 
Campbell, Shannon, Phil Chidester, Jamel Bell, and Jason Royer. 2004. "Remote control: How Mass Media Delgitimize Rioting as Social Protest." Race, Gender \& Class. 11(1):158-176.

Carmines, Edward G. and James A. Stimson. 1989. Issue Evolution: Race and the Transformation of American Politics. Princeton, NJ: Princeton University Press.

Carney, Dana R., John T. Jost, Samuel D. Gosling, and Jeff Potter. 2008. "The Secret Lives of Liberals and Conservatives: Personality Profiles, Interaction Styles, and the Things They Leave behind." Political Psychology 29(6):807-40.

Castells, Manuel. 2015. Networks of Outrage and Hope: Social Movements in the Internet Age. Cambridge, UK: Polity Press.

Cunningham, William A., John B. Nezlek, and Mahzarin R. Banaji. 2004. "Implicit and Explicit Ethnocentrism: Revisiting the Ideologies of Prejudice." Personality and Social Psychology Bulletin 30(10):1332-46.

Davenport, Christian, Sarah A. Soule, and David A. Armstrong. 2011. "Protesting While Black? The Differential Policing of American Activism, 1960 to 1990." American Sociological Review 76(1):152-178.

Diani, Mario. 2000. "Social Movement Networks Virtual and Real." Information, Communication \& Society 3(3):386-401.

Duckitt, John. 2001. "A Dual-Process Cognitive-Motivational Theory of Ideology and Prejudice." Advances in Experimental Social Psychology 33:41-113.

Doan, Long. 2016. "How Do Racial and Gender Beliefs Affect Emotions?" PhD dissertation, Department of Sociology, University of Indiana, Bloomington.

Dovidio, John F. and Samuel L. Gaertner. 2004. “Aversive Racism.” Advances in Experimental Social Psychology 36:1-52.

Ekman, Paul and Erika L. Rosenberg. 1997. What the Face Reveals: Basic and Applied Studies of Spontaneous Expression Using the Facial Action Coding System (FACS). New York, NY: Oxford University Press.

Farley, Reynolds, Charlotte Steeh, Maria Krysan, Tara Jackson, and Keith Reeves. 1994. "Stereotypes and Segregation: Neighborhoods in the Detroit Area." American Journal of Sociology 100(3):750-80.

Fassiotto, Magali and Sarah A. Soule. 2017. "Loud and Clear: The Effect of Protest Signals on Congressional Attention." Mobilization 22(1): 17-38.

Feagin, Joe R. and Eileen O’Brien. 2004. White Men on Race: Power, Privilege, and the Shaping of Cultural Consciousness. Boston, MA: Beacon Press.

Feinberg, Matthew, Robb Willer, and Chloe Kovacheff. 2017. "Extreme Protest Tactics Reduce Popular Support for Social Movements." Rottman School of Management Working Paper No. 2911177. Retrieved August 12, 2017 (https://papers.ssrn.com/sol3/papers.cfm?abstract_id=2911177). 
Flam, Helena and Debra King. 2007. Emotions and Social Movements. New York, NY: Routledge.

Gaertner, Samuel L. and John F. Dovidio. 1986. The Aversive Form of Racism. New York, NY: Academic Press.

Gaines, Brian J., James H. Kuklinski, and Paul J. Quirk. 2006. "The Logic of the Survey Experiment Reexamined.” Political Analysis 15(1):1-20.

Gamson, William A. 1992. Talking Politics. Cambridge, UK: Cambridge University Press.

Giugni, Marco G. 1998. "Was it Worth the Effort? The Outcomes and Consequences of Social Movements." Annual Review of Sociology 24:371-393.

Golder, Scott A. and Michael W. Macy. 2014. "Digital Footprints: Opportunities and Challenges for Online Social Research." Annual Review of Sociology 40:129-152.

González-Bailón, Sandra, Javier Borge-Holthofer, Alejandro Rivero, and Yami Moreno. 2011. "The Dynamics of Protest Recruitment through an Online Network." Scientific Reports 1.

Goodman, Joseph K., Cynthia E. Cryder, and Amar Cheema. 2013. "Data Collection in a Flat World: The Strengths and Weaknesses of Mechanical Turk Samples." Journal of Behavioral Decision Making 26(3):213-24.

Goodwin, Jeff, James Jasper, and Francesca Polletta. 2009. Passionate Politics: Emotions and Social Movements. Chicago, IL: University of Chicago Press.

Goodwin, Jeff, James Jasper, and Francesca Polletta. 2000. "The Return of the Repressed: The Fall and Rise of Emotions in Social Movement Theory." Mobilization: An International Quarterly 5(1):65-83.

Gould, Deborah B. 2009. Moving Politics: Emotion and ACT UP's Fight against AIDS. Chicago, IL: University of Chicago Press.

Goyette, Kimberly A. 2008. "Race, Social Background, and School Choice Options 1.” Equity and Excellence in Education 41(1):114-29.

Graham, Jesse, Jonathan Haidt, and Brian A. Nosek. 2009. "Liberals and Conservatives Rely on Different Sets of Moral Foundations." Journal Of Personality and Social Psychology 96(5):1029-46.

Hochschild, Arlie Russell. 1979. "Emotion Work, Feeling Rules, and Social Structure." American Journal of Sociology 85(3):551-75.

Hochschild, Arlie Russell. 2012[1983]. The Managed Heart: Commercialization of Human Feeling. Berkeley, CA: University of California Press.

Hutchings, Vincent L. and Nicholas A. Valentino. 2004. "The Centrality of Race in American Politics." Annual Review of Political Science 7:383-408.

Isaac, Larry. 2008. "Movement of Movements: Culture Moves in the Long Civil Rights Struggle." Social Forces 87(1):33-63.

Jasper, James M. 1998. “The Emotions of Protest: Affective and Reactive Emotions in and 
around Social Movements.” Sociological Forum 13(3):397-424.

Jasso, Guillermina. 2006. "Factorial Survey Methods for Studying Beliefs and Judgments." Sociological Methods and Research 34(3):334-423.

Jeffries, Vincent, Ralph H. Turner, and Richard T. Morris. 1971. "The Public Perception of the Watts Riot as Social Protest.” American Sociological Review 36(3):443-51.

Jost, John T. 2006. "The End of the End of Ideology.” American Psychologist 61(7):1-7

Jost, John T., Jack Glaser, Arie W. Kruglanski, and Frank J. Sulloway. 2003a. "Exceptions That Prove the Rule--Using a Theory of Motivated Social Cognition to Account for Ideological Incongruities and Political Anomalies: Reply to Greenberg and Jonas (2003)." Psychological Bulletin 129(3):383-93

Jost, John T., Jack Glaser, Arie W. Kruglanski, and Frank J. Sulloway. 2003b. "Political Conservatism as Motivated Social Cognition.” Psychological Bulletin 129(3):339-75

King, Brayden G. 2011. "The Tactical Disruptiveness of Social Movements: Sources of Market and Mediated Disruption in Corporate Boycotts." Social Problems 58(4):491-517.

King, Desmond S. and Rogers M. Smith. 2011. Still a House Divided: Race and Politics in Obama's America. Princeton, NJ: Princeton University Press.

Kruglanski, Arie W. 2013. The Psychology of Closed Mindedness. New York, NY: Psychology Press.

Krumpal, Ivar. 2013. "Determinants of Social Desirability Bias in Sensitive Surveys: A Literature Review." Quality \& Quantity 47(4):2025-2047.

Kuklinski, James H., Michael D. Cobb, and Martin Gilens. 1997. "Racial Prejudice and Attitudes Toward Affirmative Action.” American Journal of Political Science 41(2):402-19.

Lakoff, George. 1997. Moral Politics: What Conservatives Know That Liberals Don't. Chicago, IL: University of Chicago Press.

Lewis, Kevin, Kurt Gray, and Jens Meierhenrich. 2014. "The Structure of Online Activism." Sociological Science. DOI 10.15195/v1.a1

López, Ian Haney. 2015. Dog Whistle Politics: How Coded Racial Appeals Have Reinvented Racism and Wrecked the Middle Class. New York, NY: Oxford University Press.

Luttig, Matthew D., Christopher M. Federico, and Howard G. Lavine. 2017. "Supporters and Opponents of Donald Trump Respond Differently to Racial Cues: An Experimental Analysis." Research and Politics 4(4):1-8.

Marby, J. Beth and K. Jill Kicolt. 2005. "Anger in Black and White: Race, Alienation, and Anger." Journal of Health and Social Behavior 46(1):85-101.

McAdam, Doug. 2017. "Social Movement Theory and the Prospects for Climate Change Activism in the United States." Annual Review of Political Science 20:189-208.

McDonnell, Terence E., Christopher A. Bail, and Iddo Tavory. 2017. "A Theory of Resonance." Sociological Theory. 35(1):1-14. 
Mendelberg, Tali. 2001. The Race Card: Campaign Strategy, Implicit Messages, and the Norm of Equality. Princeton, NJ: Princeton University Press.

Mirchandani, Kiran. 2003. "Challenging Racial Silences in Studies of Emotion Work: Contributions from Anti-Racist Feminist Theory." Organization Studies 24(5):721-42.

Murakawa, Naomi. 2008. "The Origins of the Carceral Crisis: Racial Order as 'law and Order' in Postwar American Politics.” Pp. 235-55 in Race and American Political Development. Edited by Joseph Lowndes, Julie Novkov, and Dorian Tod Warren. New York, NY: Routledge

Nail, Paul R., Helen C. Harton, and Brian P. Decker. 2003. "Political Orientation and Modern versus Aversive Racism: Tests of Dovidio and Gaertner's (1998) Integrated Model." Journal of Personality and Social Psychology 84(4):754-70.

Nepstad, Sharon Erickson and Christian Smith. 2001. "The Social Structure of Moral Outrage in Recruitment to the US Central America Peace Movement." Pp. 158-74 in Passionate Politics: Emotions and Social Movements. Edited by Jeff Goodwin, James M. Jasper, and Francesca Polletta. Chicago, IL: University of Chicago Press.

Novkov, Julie. 2008. "Rethinking Race in American Politics.” Political Research Quarterly 61(4):649-59.

Obasogie, Osagie K. and Zachary Newman. 2016. "Black Lives Matter and Respectability Politics in Local News Accounts of Officer-Involved Civilian Deaths: An Early Empirical Assessment." Wisconsin Law Review 3:541-74.

Olson, Joel. 2008. "Whiteness and the Polarization of American Politics." Political Research Quarterly 61(4):704-18.

Omi, Michael and Howard Winant. 2014. Racial Formation in the United States. New York, NY: Routledge.

Paolacci, Gabriele, Jesse Chandler, and Panagiotis G. Ipeirotis. 2010. "Running Experiments on Amazon Mechanical Turk." Judgment and Decision Making 5(5):411-419.

Pearson, Adam R., John F. Dovidio, and Samuel L. Gaertner. 2009. "The Nature of Contemporary Prejudice: Insights from Aversive Racism." Social and Personality Psychology Compass 3(3):314-38.

Quillian, Lincoln. 2002. "Why Is Black-White Residential Segregation so Persistent?: Evidence on Three Theories from Migration Data.” Social Science Research 31(2):197-229.

Raftery, Adrian E. 1995. "Bayesian Model Selection in Social Research.” Sociological Methodology 25:111-63.

Robinson, Dawn T. and Lynn Smith-Lovin. 1999. "Emotion Display as a Strategy for Identity Negotiation." Motivation and Emotion 23(2):73-104.

Rojas, Fabio. 2006. "Social Movement Tactics, Organizational Change and the Spread of African-American Studies.” Social Forces 84(4):2147-66.

Rojas, Fabio. 2007. From Black Power to Black Studies: How a Radical Social Movement 
Became an Academic Discipline. Baltimore, MD: JHU Press.

Saporito, Salvatore and Annette Lareau. 1999. "School Selection as a Process: The Multiple Dimensions of Race in Framing Educational Choice.” Social Problems 46(3):418-39.

Saucier, Donald A., Carol T. Miller, and Nicole Doucet. 2005. "Differences in Helping Whites and Blacks: A Meta-Analysis.” Personality and Social Psychology Review 9(1):2-16.

Schussman, Alan and Sarah A. Soule. 2005. "Process and Protest: Accounting for Individual Protest Participation." Social Forces 84(2):1083-1108.

Schwalbe, Michael, Daphne Holden, Douglas Schrock, Sandra Godwin, Shealy Thompson, and Michele Wolkomir. 2000. "Generic Processes in the Reproduction of Inequality: An Interactionist Analysis." Social Forces 79(2):419-52.

Sears, David O. and Patrick J. Henry. 2003. “The Origins of Symbolic Racism.” Journal of Personality and Social Psychology 85(2):259-75.

Sears, David O., Colette Van Laar, Mary Carrillo, and Rick Kosterman. 1997. "Is It Really Racism?: The Origins of White Americans' Opposition to Race-Targeted Policies." The Public Opinion Quarterly 61(1):16-53.

Shields, Stephanie A. 2005. "The Politics of Emotion in Everyday Life:' Appropriate' Emotion and Claims on Identity." Review of General Psychology 9(1):3-15.

Sidanius, Jim, Felicia Pratto, and Lawrence Bobo. 1996. "Racism, Conservatism, Affirmative Action, and Intellectual Sophistication: A Matter of Principled Conservatism or Group Dominance?" Journal of Personality and Social Psychology 70(3):476-90.

Simons, Daniel J. and Christopher F. Chabris. 2012. "Common (Mis) Beliefs about Memory: A Replication and Comparison of Telephone and Mechanical Turk Survey Methods." PloS One 7(12):e51876.

Simpson, Brent, Robb Willer, and Matthew Feinberg. 2018. "Does Violent Protest Backfire? Testing a Theory of Public Reactions to Activist Violence." Socius 4:1-14.

Snow, David A., Louis A. Zurcher, Jr., and Sheldon Eckland-Olson. 1980. "Social Networks and Social Movements: A Microstructural Approach to Differential Recruitment." American Sociological Review 45(5):787-801.

Snow, David A., E. Burke Rochford, Jr., Steven K. Worden, and Robert D. Benford. 1986. "Frame Alignment Processes, Micromobilization, and Movement Participation." American Sociological Review 51(4):464-481.

Snow, David A. and Robert D. Benford. 1988. "Ideology, Frame Resonance, and Participant Mobilization." International Social Movements Research 1:197-217.

Soroka, Stuart N. and Christopher Wlezien. 2010. Degrees of Democracy: Politics, Public Opinion, and Policy. Cambridge, UK: Cambridge University Press.

Stephan, Maria J., and Erica Chenoweth. 2008. "Why Civil Resistance Works: The Strategic Logic of Nonviolent Conflict.” International Security 33(1):7-44 
Stephens-Davidowitz, Seth. 2014. "The Cost of Racial Animus on a Black Candidate: Evidence Using Google Search Data.” Journal of Public Economics 118:26-40.

Thoits, Peggy A. 1989. “The Sociology of Emotions.” Annual Review of Sociology 15:317-42.

Thomas, Emma F., and Winnifred R. Louis. 2014. "When Will Collective Action Be Effective? Violent and Non-violent Protests Differentially Influence Perceptions of Legitimacy and Efficacy among Sympathizers." Personality and Social Psychology Bulletin 40(2):263-76.

Turner, Jonathan H. 2007. Human Emotions: A Sociological Theory. London, UK: Taylor and Francis.

Turner, Jonathan H. and Jan E. Stets. 2005. The Sociology of Emotions. Cambridge: Cambridge University Press.

Valentino, Nicholas A. and David O. Sears. 2005. "Old Times There Are Not Forgotten: Race and Partisan Realignment in the Contemporary South." American Journal of Political Science 49(3):672-88.

Van Laer Jeroen and Peter Van Aelst. 2010. "Internet and Social Movement Action Repertoires: Opportunities and Limitations." Information, Communication \& Society 13(8):1146-1171.

Van Stekelenburg, Jacquelien and Bert Klandermans. 2013. "The Social Psychology of Protest." Current Sociology 61(5-6):886-905.

Virtanen, Simo V and Leonie Huddy. 1998. "Old-Fashioned Racism and New Forms of Racial Prejudice." The Journal of Politics 60(2):311-32.

Wasow, Omar. 2017. "Do Protests Matter? Evidence from the 1960s Black Insurgency." Unpublished manuscript, Princeton University, Princeton, NJ

Webster, Murray and Jane Sell. 2014. Laboratory Experiments in the Social Sciences. Waltham, MA: Elsevier.

Weinberg, Jill D., Jeremy Freese, and David McElhattan. 2014. "Comparing Data Characteristics and Results of an Online Factorial Survey between a Population-Based and a CrowdsourceRecruited Sample." Sociological Science 1:292-310.

Whitley Jr, Bernard E. 1999. "Right-Wing Authoritarianism, Social Dominance Orientation, and Prejudice." Journal of Personality and Social Psychology 77(1):126.

Wilkins, Amy. 2012. “'Not Out to Start a Revolution’ Race, Gender, and Emotional Restraint among Black University Men.” Journal of Contemporary Ethnography 41(1):34-65.

Wilson, Glenn D. 1973. The Psychology of Conservatism. New York, NY: Academic Press.

Williams, David R. and Ruth Williams-Morris. 2000. "Racism and Mental Health: The African American Experience." Ethnicity and Health 5(3-4):243-68.

Wingfield, Adia Harvey. 2007. "The Modern Mammy and the Angry Black Man: African American Professionals' Experiences with Gendered Racism in the Workplace.” Race, Gender, \& Class 14(1/2):196-212.

Wingfield, Adia Harvey. 2010. “Are Some Emotions Marked‘ whites Only’? Racialized Feeling 
Rules in Professional Workplaces." Social Problems 57(2):251-68.

Wouters, Ruud and Stefaan Walgrave. 2017. "Demonstrating Power: How Protest Persuades Political Representatives." American Sociological Review 82(2):361-383. 
Figure A1. Neutral White Manipulation

\section{THE WALL STREET JOURNAL. \\ Further Protests Planned Across the Country Over Police Shootings}

By ZUSHA ELINSON and MARK PETERS
Updated Nov. 26, 2015 8:12 p.m. ET

In several major cities across the U.S., people are uniting to demand changes in policing strategies. There have been increasing calls for investigations into local police departments' use of force following the high-profile shootings of unarmed teenagers.

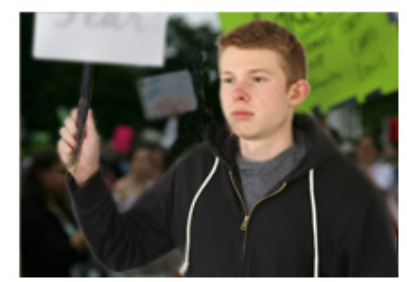

Figure A2. Angry White Manipulation

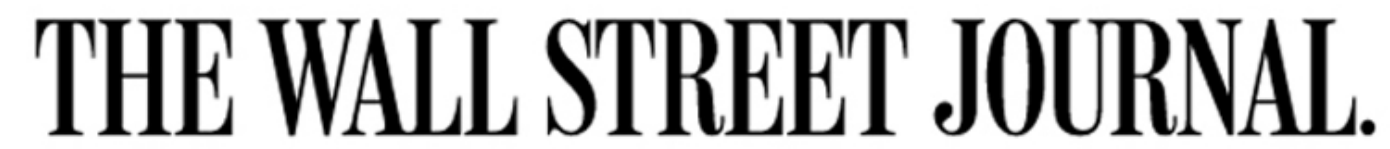

\section{Further Protests Planned Across the Country Over Police Shootings}

BY ZUSHA ELINSON and MARK PETERS Updated Nov. 26, 2015 8:12 p.m. ET

In several major cities across the U.S., people are uniting to demand changes in policing strategies. There have been increasing calls for investigations into local police departments' use of force following the high-profile shootings of unarmed teenagers.

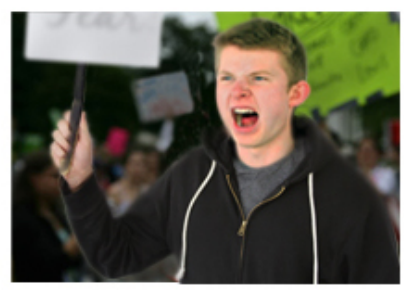


Figure A3. Neutral Black Manipulation

\section{THE WALL STREET JOLRNAL. \\ Further Protests Planned Across the Country Over Police Shootings}

BY ZUSHA ELINSON and MARK PETERS Updated Nov. 26, 2015 8:12 p.m. ET

In several major cities across the U.S., people are uniting to demand changes in policing strategies. There have been increasing calls for investigations into local police departments' use of force following the high-profile shootings of unarmed teenagers.

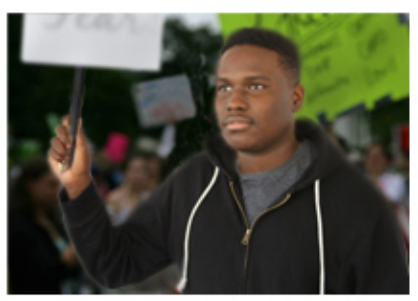

Figure A4. Angry Black Manipulation

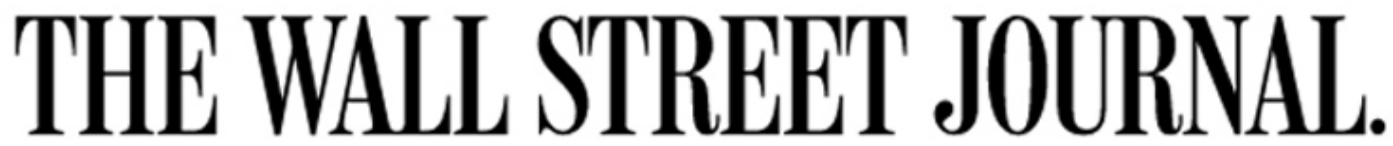

\section{Further Protests Planned Across the Country Over Police Shootings}

BY ZUSHA ELINSON and MARK PETERS

Updated Nov. 26, 2015 8:12 p.m. ET

In several major cities across the U.S., people are uniting to demand changes in policing strategies. There have been increasing calls for investigations into local police departments' use of force following the high-profile shootings of unarmed teenagers.

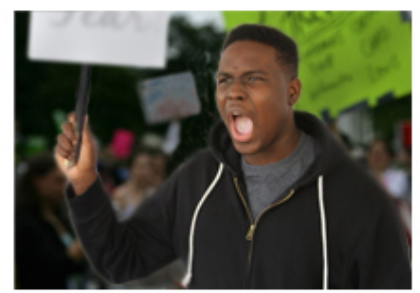




\section{APPENDIX B: Text of Petition Used in Behavioral Outcome}

\section{Figure A5. Petition}

If you would like to sign the following petition from Change.org to urge the federal government to require every police department that receives federal aid to report shootings of unarmed teenagers to the FBI, please provide your information below. Otherwise, you may continue to the next question.

\section{Name}

Email address

Comment

SIGN THE PETITION 


\section{APPENDIX C: Study Sample Demographics Compared to U.S. Population}

Table A1. Study Sample Demographics Compared to U.S. Population

\begin{tabular}{|c|c|c|}
\hline & $\begin{array}{c}\text { Study } \\
\text { sample }\end{array}$ & $\begin{array}{c}\text { US } \\
\text { population }\end{array}$ \\
\hline Female $^{1}$ & .466 & .508 \\
\hline White $^{1}$ & .744 & .731 \\
\hline Age & 34.6 & 37.8 \\
\hline Protestant $^{1}$ & .277 & .474 \\
\hline College degree ${ }^{1}$ & .536 & .306 \\
\hline Household income & 56213 & 55775 \\
\hline Conservatism $^{2}$ & 3.40 & 4.08 \\
\hline
\end{tabular}

NOTE: ${ }^{1}$ Numbers presented represent proportion falling in this category.

${ }^{2}$ Conservatism is measured on a scale from $1-7$, where $1=$ "extremely liberal" and $7=$ "extremely conservative"

US figures are drawn from 2015 American Community Survey; religious affiliation and political views are drawn from 2016 General Social Survey. US age and household income values shown are the median. 


\section{APPENDIX D: Results for Moderates}

Table A2. Effects for Political Groups Including Moderates

\begin{tabular}{|c|c|c|c|c|}
\hline & $\begin{array}{c}\text { Sign } \\
\text { petition }^{\mathrm{a}}\end{array}$ & $\begin{array}{c}\text { Protest } \\
\text { justified }^{b}\end{array}$ & $\begin{array}{l}\text { Attend } \\
\text { rally }^{\mathrm{b}}\end{array}$ & $\begin{array}{l}\text { Perceived } \\
\text { violence }^{\text {b }}\end{array}$ \\
\hline $\begin{array}{l}\text { Black } \\
\text { protestor } \\
\text { (conservative } \\
\text { bystander) }\end{array}$ & $-.347 *(.140)$ & $-.187 * *(.069)$ & $-.178 *(.079)$ & $.196 *(.076)$ \\
\hline $\begin{array}{l}\text { White } \\
\text { protestor } \\
\text { (moderate } \\
\text { bystander) }\end{array}$ & $-.118(.139)$ & $.501 * * *(.074)$ & $.299 * * *(.085)$ & $-.290 * * *(.081)$ \\
\hline $\begin{array}{l}\text { Black } \\
\text { protestor } \\
\text { (moderate } \\
\text { bystander) }\end{array}$ & $.151(.129)$ & $.424 * * *(.073)$ & $.297 * * *(.085)$ & $-.176 *(.080)$ \\
\hline $\begin{array}{l}\text { White } \\
\text { protestor } \\
\text { (liberal } \\
\text { bystander) }\end{array}$ & $.379 * * *(.105)$ & $1.053 * * *(.060)$ & $.866 * * *(.069)$ & $-.703 * * *(.066)$ \\
\hline $\begin{array}{l}\text { Black } \\
\text { protestor } \\
\text { (liberal } \\
\text { bystander) }\end{array}$ & $.556 * * *(.104)$ & $1.090 * * *(.060)$ & $.982 * * *(.069)$ & $-.577 * * *(.066)$ \\
\hline Constant & $-1.269 * * *(.091)$ & $3.455 * * *(.049)$ & $1.804 * * *(.057)$ & $3.804 * * * 9.054)$ \\
\hline $\mathrm{N}$ & 2816 & 2816 & 2816 & 2816 \\
\hline
\end{tabular}




\section{APPENDIX E: Results Excluding Black Participants}

Table A3. Effects With and Without Black Bystanders

\begin{tabular}{|c|c|c|c|c|c|c|}
\hline & \multicolumn{2}{|c|}{ Sign petition $^{\mathrm{a}}$} & \multicolumn{2}{|c|}{ Protest justified $^{\mathrm{b}}$} & \multicolumn{2}{|c|}{ Attend rally ${ }^{b}$} \\
\hline & $\begin{array}{l}\text { All } \\
\text { bystanders }\end{array}$ & $\begin{array}{l}\text { No Black } \\
\text { bystanders }\end{array}$ & $\begin{array}{l}\text { All } \\
\text { bystanders }\end{array}$ & $\begin{array}{l}\text { No Black } \\
\text { bystanders }\end{array}$ & $\begin{array}{l}\text { All } \\
\text { bystanders }\end{array}$ & $\begin{array}{l}\text { No Black } \\
\text { bystanders }\end{array}$ \\
\hline $\begin{array}{l}\text { Black } \\
\text { protestor } \\
\text { (conservative } \\
\text { bystander) }\end{array}$ & $\begin{array}{l}-.347^{*} \\
(.140)\end{array}$ & $\begin{array}{l}-.334 * \\
(.144)\end{array}$ & $\begin{array}{l}-.187 * * \\
(.068)\end{array}$ & $\begin{array}{l}-.150 * \\
(.069)\end{array}$ & $\begin{array}{l}-.180 * \\
(.079)\end{array}$ & $\begin{array}{l}-.159 * \\
(.079)\end{array}$ \\
\hline $\begin{array}{l}\text { White } \\
\text { protestor } \\
\text { (liberal } \\
\text { bystander) }\end{array}$ & $\begin{array}{l}.379 * * * \\
(.105)\end{array}$ & $\begin{array}{l}.384 * * * \\
(.109)\end{array}$ & $\begin{array}{l}1.053 * * * \\
(.059)\end{array}$ & $\begin{array}{l}1.090 * * * \\
(.061)\end{array}$ & $\begin{array}{l}.866 * * * \\
(.069)\end{array}$ & $\begin{array}{l}.868 * * * \\
(.070\end{array}$ \\
\hline $\begin{array}{l}\text { Black } \\
\text { protestor } \\
\text { (liberal } \\
\text { bystander) }\end{array}$ & $\begin{array}{l}.556 * * * \\
(.104)\end{array}$ & $\begin{array}{l}.556 * * * \\
(.108)\end{array}$ & $\begin{array}{l}1.090 * * * \\
(.059)\end{array}$ & $\begin{array}{l}1.143 * * * \\
(.061)\end{array}$ & $\begin{array}{l}.982 * * * \\
(.069)\end{array}$ & $\begin{array}{l}1.007 * * * \\
(.070)\end{array}$ \\
\hline Constant & $\begin{array}{l}-1.269 * * * \\
(.091)\end{array}$ & $\begin{array}{l}-1.29 * * * \\
(.094)\end{array}$ & $\begin{array}{l}3.455^{* * *} \\
(.049) \\
\end{array}$ & $\begin{array}{l}3.394 * * * \\
(.050)\end{array}$ & $\begin{array}{l}1.804 * * * \\
(.057) \\
\end{array}$ & $\begin{array}{l}1.758 * * * \\
(.057)\end{array}$ \\
\hline $\mathrm{N}$ & 2230 & 2073 & 2230 & 2073 & 2230 & 2073 \\
\hline
\end{tabular}

